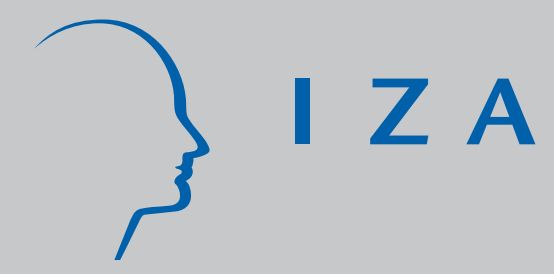

IZA DP No. 3573

Examining the Gender Wealth Gap in Germany

Eva M. Sierminska

J oachim R. Frick

Markus M. Grabka

J une 2008 


\title{
Examining the Gender Wealth Gap in Germany
}

\author{
Eva M. Sierminska \\ CEPS/INSTEAD and DIW Berlin \\ Joachim R. Frick \\ DIW Berlin, TU Berlin and IZA \\ Markus M. Grabka \\ DIW Berlin
}
Discussion Paper No. 3573
June 2008

\author{
IZA \\ P.O. Box 7240 \\ 53072 Bonn \\ Germany \\ Phone: +49-228-3894-0 \\ Fax: +49-228-3894-180 \\ E-mail: iza@iza.org
}

\begin{abstract}
Any opinions expressed here are those of the author(s) and not those of IZA. Research published in this series may include views on policy, but the institute itself takes no institutional policy positions.

The Institute for the Study of Labor (IZA) in Bonn is a local and virtual international research center and a place of communication between science, politics and business. IZA is an independent nonprofit organization supported by Deutsche Post World Net. The center is associated with the University of Bonn and offers a stimulating research environment through its international network, workshops and conferences, data service, project support, research visits and doctoral program. IZA engages in (i) original and internationally competitive research in all fields of labor economics, (ii) development of policy concepts, and (iii) dissemination of research results and concepts to the interested public.
\end{abstract}

IZA Discussion Papers often represent preliminary work and are circulated to encourage discussion. Citation of such a paper should account for its provisional character. A revised version may be available directly from the author. 


\section{ABSTRACT}

\section{Examining the Gender Wealth Gap in Germany*}

Welfare-oriented analyses of economic outcome measures such as income and wealth generally rest on the assumption of pooled and equally shared resources among all household members. Yet the lack of individual-level data hampers the distribution of income and wealth within the household context. Based on unique individual-level wealth data from the German Socio-Economic Panel (SOEP), this paper challenges the implicit assumption of internal redistribution by considering an alternative definition of the aggregation unit and by controlling its effect on distribution and inequality analysis. We find empirical evidence for a significant gender wealth gap of about 30,000 euros in Germany, which amounts to almost 50,000 euros for married partners. Decomposition analyses reveal that this gap is mostly driven by differences in characteristics between men and women, the most important factor being the individual's own income and labor market experience, and particularly so at the bottom and top of the wealth distribution. However, this finding can only be shown with nonparametric decomposition techniques. Differences for those in the middle of the distribution appear to be mostly driven by the wealth function, i.e., the way in which women transform their characteristics into wealth.

JEL Classification: $\quad$ D13, D31, D69, I31

Keywords: wealth gap, wealth inequality, gender, SOEP

Corresponding author:

Eva Sierminska

CEPS/INSTEAD

BP 48

L-4501 Differdange

Luxembourg

E-mail: eva.sierminska@ceps.lu

\footnotetext{
For Sierminska, this work is part of the MeDIM project (Advances in the Measurement of Discrimination, Inequality and Mobility) supported by the Luxembourg 'Fonds National de la Recherche' (contract FNR/06/15/08) and by core funding for CEPS/INSTEAD by the Ministry of Culture, Higher Education and Research of Luxembourg. Frick and Grabka thank the Hans-BöcklerFoundation for financial support via the project on "Income and Wealth Distribution" (HBS-Project-Nr. 2006-835-4). The authors would like to thank Vincent Hildebrand, Philippe van Kerm, the participants of the LWS Final "Beta Phase" Conference, the $2^{\text {nd }}$ ECINEQ meeting and the 2008 Scottish Economic Society conference for helpful suggestions and comments. All remaining errors are ours.
} 


\section{Table of Contents}

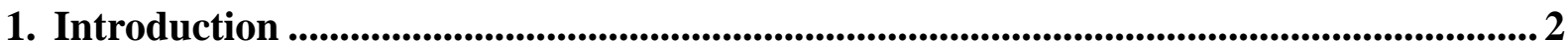

2. Background information: Wealth accumulation and empirical evidence ......................3

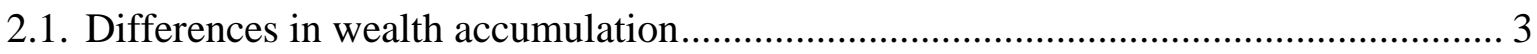

2.2. Gender differences in wealth accumulation......................................................... 4

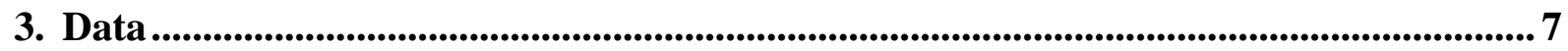

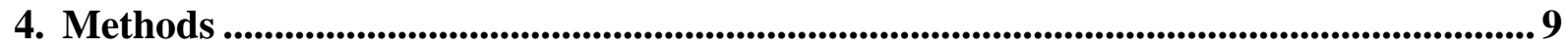

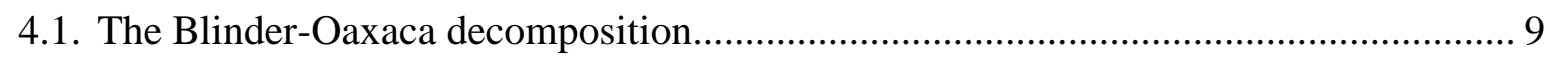

4.2. The Juhn, Murphy, \& Pierce decomposition ............................................................. 10

4.3. Nonparametric Methods for Group Comparisons ...................................................... 11

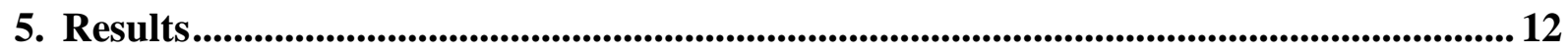

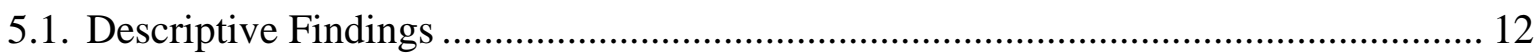

5.2. Some Facts about "Equal Sharing" among Couples in Germany ............................... 14

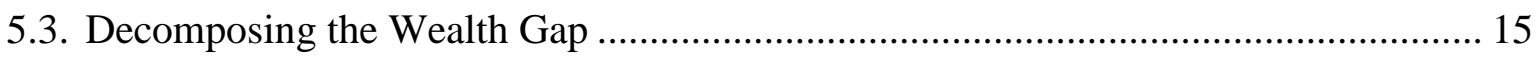

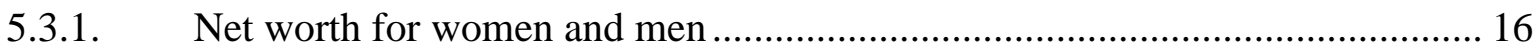

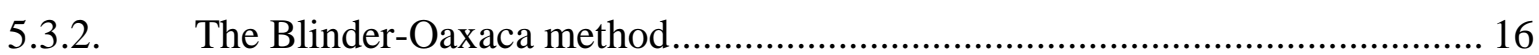

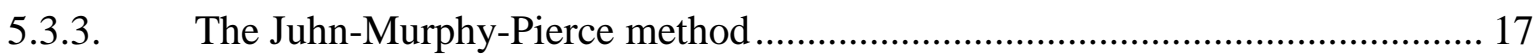

5.3.4. The DiNardo-Fortin-Lemieux method .......................................................... 19

5.3.5. Comparison of results derived from various decomposition techniques........... 20

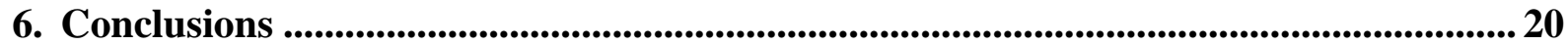

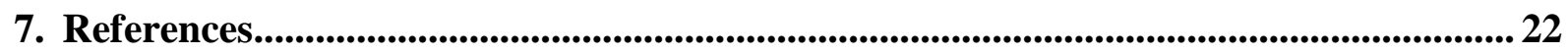

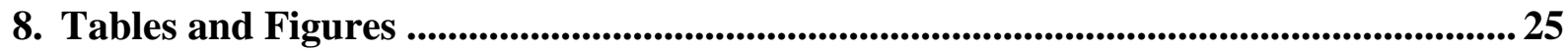

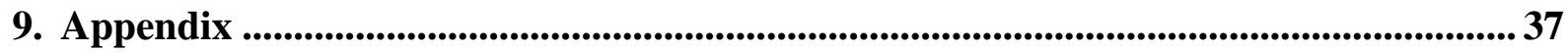




\section{Introduction}

Welfare-oriented analyses of economic outcome measures such as income and wealth generally rest on the assumption that household resources are pooled and shared equally among its members; or in a wider definition, that all individuals have equal control over these resources. Yet some studies have demonstrated that household and individual welfare are not the same (e.g., Phipps \& Burton 1995), while the lack of individual-level data consistently hampers investigation of the income and wealth distribution within the household. The inability to differentiate asset ownership within the household forces many wealth studies to focus on differences in family structures (see, e.g., Zagorsky (1999), Yamokoski \& Keister (2006), Schmidt and Sevak (2006), Sedo \& Kossoudji (2004)).

Due to the lack of the appropriate individual wealth data, empirical papers often rely on the implicit assumption of equally sharing wealth across members of the same households. This paper challenges this approach by considering an alternative definition of the aggregation unit and by controlling its effect on distribution and inequality analysis (including the decomposition of inequality). We use the unique individual level wealth data of the German Socio-Economic Panel (SOEP) study and examine the existence of a gender wealth gap throughout the wealth distribution. Frick, Grabka, and Sierminska (2007) provide empirical evidence on the extent to which the implicit household internal wealth redistribution masks the "true" degree of inequality within households: using households as the aggregation unit and applying per-capita household wealth to all household members yields a Gini coefficient for net worth of about .70, which is about $8 \%$ less than that obtained from individual wealth information (.76). For a more top-sensitive inequality measure like the halfsquared coefficient of variation, the reduction is much stronger: about $25 \%$.

In this paper, we use the semiparametric decomposition approach devised by DiNardo, Fortin, and Lemieux (1996) to document disparities in individual wealth that exist between the sexes. To assess the sensitivity of our results, we compare them to those obtained using the decompositions developed by Oaxaca and Blinder (Oaxaca 1973; Blinder 1973) as well as by Juhn, Murphy, and Pierce (1993). While our focus is on differentials within the household, we also document differences among other family types and by marital status (married, cohabiting, never married, widowed, and divorced) (see also Zagorsky 1999). Descriptive analyses provide evidence for a significant "raw" gender wealth gap in Germany of approximately 30,000 euros, which widens to about 50,000 euros for men and women living 
in couple-headed households. Among married households, we find that only $15 \%$ of these declare an even distribution of assets, thus giving strong support for the need to collect and analyze wealth at the individual level.

This paper is organized as follows: Focusing on gender-specific aspects, Section 2 provides background information on wealth accumulation and reviews the relevant literature. Data and decomposition methods are described in Sections 3 and 4, respectively. Section 5 gives the empirical results of the wealth decomposition. Section 6 concludes by pointing to open research questions.

\section{Background information: Wealth accumulation and empirical evidence}

\subsection{Differences in wealth accumulation}

In a simple model of accumulation, assets in period $t+1\left(A_{t+1}\right)$ can be expressed via the following equation $A_{t+1}=(1+r)\left(A_{t}+Y_{t}-C_{t}\right)$

where $(r)$ is the gross rate of return on investments, $\left(Y_{t}\right)$ denotes income in period $t$ and $\left(C_{t}\right)$ is consumption in period t.

In this model, the assets in period $t+1$ may be different for several reasons. First, of all differences in saving $\left(Y_{t}-C_{t}\right)$ will result in a different accumulation of assets. The amount saved will in turn depend on the level of income, age and risk-aversion. For example, households with the same saving rate will have different outcomes if their saving patterns are based on different levels of income. Younger households are also expected to have accumulated less wealth (Modigliani and Brumberg (1954); Friedman (1957)) due to their different position in the life-cycle compared to the elderly. The presence of risk aversion will affects precautionary saving levels (Kimball (1990); Zeldes (1989)). Due to uncertainty about future income and in case of liquidity constraints that prevent a household from borrowing, risk-averse households are expected to accumulate additional wealth in order to prevent a future drop in consumption caused by a negative income shock. As a result, households may differ in saving rates depending on their preferences and current consumption needs in the presence of liquidity constraints.

In addition, households differ in their preference for risk, which translates to different rates of return based on their preferred portfolio allocations. Via $(r)$ in equation (1) these 
choices translate into different levels of assets in period $t+1$. Finally, households may enter the period with different stocks of assets (A), possibly due to inheritance resulting in differences in $\left(A_{t+1}\right)$.

\subsection{Gender differences in wealth accumulation}

Any persistent differences between women and men in the aforementioned factors will lead to gender differences in wealth accumulation. Empirical evidence indicates gender differences in many areas.

First of all, women and men differ in their attachment to the labor market. According to Warren et al. 2001 any disadvantage in net worth is partly the result of lower female labor force participation The standard pattern is a continuous full-time labor market attachment for male breadwinners, while women tend to have part-time work arrangements (including potential wage penalties; see Bardasi and Gornick, 2008), often with more diversified work histories due to child bearing and child rearing and more frequent job changes (Berger and Denton, 2004).

Differences in earnings are another potential source of the wealth gap. Given a persistent gender gap in earnings, even when holding savings rates constant, women are expected to accumulate lower levels of wealth (Blau and Kahn (1997, 2000) O’Neill (2003) Moore and Shierholz (2004)).

There is evidence that women and men differ in the risk preference and hence, returns to savings as women invest more conservatively in their portfolios, which leads us to expect lower returns to wealth (Bajtelsmit and Van Derhei (1997), Hinz, McCarthy and Turner (1997), Jiankokopolos and Bernasek (1998)). Also Brush et al. (2002) find that a relative lack of social networks reduces women's access to venture capital, thus leaving them out of this particular avenue of wealth creation.

Authors have also extensively pointed out differences between women and men in the probability of owning a home. This is the most important component of the household wealth portfolio, additionally providing a flow of services and opportunities to accumulate wealth. One of the factors leading to gender differences in homeownership is discrimination in mortgage lending. Ladd (1998) found evidence of discrimination prior to the 1974 Equal Credit Opportunity Act (ECOA) in explicit bank policies. More recently, Robinson (2002) 
found that gender and family structure discrimination depends on race. In the US, white couples face discrimination if the wife works, while African American couples face discrimination if the wife stays at home. These patterns also hold for households with a single female household head. White single mothers are at a relative disadvantage, while single African American mothers appear to be helped by the presence of children. The second barrier to homeownership for women is that women earn less than men on average and higher incomes are associated with an increased ability to save and with higher credit scores.

Differences in family structures have been found to be important in explaining the gender wealth gap. For example, Sedo and Kossoudji (2004) find that married households are significantly more likely to own a home than non-married couple-headed households and other households [there may be an endogeneity problem here, since married individuals may exhibit characteristics similar to those of individuals who invest in owner-occupied housing]. They also find that family type is associated with further differences than just gender. Women are more likely than men to live in single-earner households with children (the majority of single parents are women) and are thus less likely to be wealthy. Schmidt and Sevak (2006) find large differences in observed wealth between single households and married coupleheaded households throughout the wealth distribution. They also find that single women hold significantly less wealth than single men. Using the Blinder-Oaxaca decomposition they find that a significant portion of the wealth gap remains unexplained. They cannot identify wealth gaps by gender and family type for younger individuals (25-39 years old) and suggest that these emerge later in life. Mohanty (2004) examines wealth holdings after divorce using PSID data for the 1990s. She finds that single females hold significantly lower levels of wealth than single males. In this case, child support has a positive effect on women's wealth after a divorce-after controlling for the economic and personal characteristics of her household. Levine, Mitchell, and Moore (2000) look at older households and find that non-married households are considerably less well-off than married couples, even after controlling for differences in household size. Using the Health and Retirement Study (HRS) in the years before retirement, they also find sizeable gender gaps in both current and projected retirement income. Lupton and Smith (2003) also use the HRS to analyze the relationship between household type and asset accumulation, and also find that married households have more than twice the net worth of other types of households. 
Differences in marriage patterns among women and men also are found to make a difference in wealth accumulation. In a study by Wedgwood (1939), it was argued that the most important determinants for wealth endowments of women are marriage and inheritances, and this was confirmed by (Harbury and Hitchens 1977). In a more recent study, Zagorsky (1999) also finds that differences in wealth holdings are strongly affected by marital status. She finds that among the baby boomers (born between 1957 and 1964) women hold more assets on average than men. However, among unmarried households, men hold greater assets than women, while the household assets of married women tend to be greater than the household assets of married men. She explains this on the basis of gender differences in marriage patterns. Since women tend to marry men who are a few years older (Gibson, Le and Scobie (2006)), their households have had several additional years in which to accumulate wealth (including possible inheritances, which may also have a gender bias).

When looking at gender differences in wealth, some studies compare men and women in one-person households only, because surveys typically collect wealth information at the household level only. Other studies focus on individual wealth components, where data such as pension wealth is available at the individual level (see Warren 2006). In many of the studies mentioned above, a major problem is that datasets on household wealth cannot assign asset ownership to one or the other spouse. Consequently, there has been little attempt to decompose wealth differentials by gender and there is not much that can be said about the financial well-being of married women (with respect to wealth holdings) although feminist economics emphasizes the importance of looking at intra-household inequality (Blumberg (1988); Haddad and Kanbur (1990); Phipps and Burton (1994); Sen (1990) and Woolley (1993), Pahl (2001), Allmendinger et al. (2006), Deere and Doss (2006)).

One of the rare studies at the individual level is by Bolin and Pålsson (2001), utilizing wealth data for Sweden and examining the importance of family structure on wealth accumulation. They find that cohabiting and married women are compensated for lost opportunities in the labor market by larger shares of the family's non-human wealth being assigned to them.

When looking at the different levels of wealth accumulation between men and women in general and within married couples in particular, one should also consider the institutional and legal environment providing the setting for accumulation. A good example is divorce law, which can significantly affect the net worth of a former marriage. As such it is important to 
note that the legal regulations in Germany and many other European countries consider joint ownership of assets (and debts) only for those wealth components acquired during marriage. Wealth accumulated prior to marriage will remain in the hands of the original owner and will not be affected by a divorce. Inheritances during marriage are also not considered to be accumulated jointly and thus will remain fully in the hands of the successor. However, this is true for the (monetary value) of the original inheritance only and excludes capital gain or added value. Marriage contracts can also be designed to deviate from these standard regulations in divorce law. Thus, to test the actual equal sharing of resources within the family it is important to know which partner has the factual command over wealth given that in case of a divorce only the jointly accumulated wealth will be evenly split among the partners.

In this paper we have the unique opportunity to examine this aspect of household behavior by having individual ownership information of various subcomponents of wealth within households using the 2002 wealth module of the German Socio-Economic Panel (SOEP).

\section{Data}

The Socio-Economic Panel (SOEP) is a representative longitudinal survey of individuals living in private households in Germany (Wagner et al. 2007). The survey was started in 1984 in West Germany and was extended to East Germany in 1990. The initial sample included over 12,000 respondents, with everyone aged 17 and over in sample households being interviewed. In the years 1995, 1998, 2000, 2002, and 2006, new subsamples were drawn which approximately doubled the initial sample size. The sample analyzed here comprises approximately 12,700 households with about 24,000 respondents (plus their children) surveyed in the year 2002. In that year, a specific section of the individual questionnaire focused on information about wealth.

Respondents were asked to provide seven different wealth and debt components:

○ owner-occupied property (and associated debt)

$\circ$ other property (and associated debt),

○ financial assets,

○ private pensions (including life insurance and building savings contracts),

○ business assets,

$\circ$ tangible assets, and 
consumer credits.

Potential shortcomings of this rather comprehensive questionnaire arise from the exclusion of cars in the measure of tangible assets and the lack of information about pension entitlements both from company pensions and from the statutory social pension fund in Germany ("Gesetzliche Rentenversicherung"). The latter information is difficult to obtain through surveys because entitlements from these two security systems are not well known. A further restriction comes from the use of a lower threshold of 2,500 euros for financial and tangible assets and for consumer credits. This was introduced to reduce the burden on respondents by not asking them to state (rather) negligible amounts. As such, the overall measure of total wealth and the share of wealth holders are likely to be somewhat understated and biased against very small wealth holdings. A further restriction of the SOEP 2002 wealth questionnaire arises due to the lack of wealth information on children. SOEP collects wealth information from respondents starting at the age of 17 . Thus any wealth held by younger persons is not considered here-although it may have been captured if a household-based questionnaire was used. In any case, given the minor relevance of wealth holdings by children this aspect can be neglected.

A more serious problem in collecting (representative) wealth data at the micro-level is measurement error from various sources such as rounding, misreporting and very likely underreporting (e.g., financial assets), and particularly because of non-response (see, e.g., Riphahn \& Serfling 2005). On the one hand, asking separately all adult household members instead of just one reference member may increase the probability of getting all wealth components of all household members, as well as a better estimate of the true wealth of each individual. On the other hand, however, this also increases the probability of inconsistent information (e.g., two partners providing non-matching information on the very same issue such as a commonly owned home). With respect to missing information due to item nonresponse on wealth questions, the non-participation of a household reference person results in completely missing data, while the non-participation of one individual results only in partially missing data. Nevertheless, coping with all these measurement problems is a major task. In case of the SOEP wealth data used here, inconsistencies have been taken care of by means of editing on a case-wise basis, while missing data due to item non-response as well as partial unit non-response (i.e., non-responding individuals in otherwise responding households) have 
been corrected for by multiple imputation techniques, explicitly considering the potential selectivity of the underlying missing mechanisms. ${ }^{1}$

Despite these shortcomings and empirical problems, when the total wealth of private households measured by SOEP 2002 is compared to corresponding aggregated information from national balance sheets, the survey does quite well (see Frick, Grabka and Sierminska (2007)). Housing wealth components match very well as do net business assets. The biggest discrepancy is for the more heterogeneous categories financial assets and tangible assets, but in these two cases the questions ask to only report balances over 2500 euros and, more relevant, do not refer to all the components found in the aggregates included in the national balance sheets. The overall value of "financial assets" owned by a given person might consist of numerous single items and forgetting one of those yields a higher probability of understating the true value. This is less likely in the case of housing wealth, given that most people will not hold more than one home. Nevertheless, the coverage of financial assets as a percent of national balance sheet aggregates is as high as 50\% (see Frick, Grabka, and Marcus 2007), which is a very good result when compared to other surveys contained in the Luxembourg Wealth Study (LWS) besides the SOEP (see http://www.lisproject.org/lwstechdoc.htm and Sierminska, Brandolini and Smeeding (2006)).

\section{Methods}

After providing more descriptive information and bivariate analyses on wealth endowments and inequality by gender and marital status (see Section 5 below) we will invest in a gender decomposition concentrating on males and females living in partnerships (married or cohabiting). ${ }^{2}$ For sensitivity purposes we will apply various decomposition techniques, as each of them exhibits certain strengths and weaknesses.

\subsection{The Blinder-Oaxaca decomposition}

We first use the Blinder-Oaxaca method to decompose the mean difference of wealth between men and women into portions attributable to differences in the distribution of endowments (explanatory variables) and differences in returns to these endowments

\footnotetext{
${ }^{1}$ See Frick, Grabka, and Marcus 2007 for an extensive description of the editing and imputation routines and Frick, Grabka and Sierminska 2007 for an assessment of the impact of such post-survey data treatment on substantive research results such as wealth composition and inequality.

${ }^{2}$ For an introduction to various decomposition methods consult Jenkins and Van Kerm (forthcoming).
} 
(coefficients, conditional expectation functions) (see Blinder 1973; Oaxaca 1973). While this method is a very popular decomposition technique, it requires a parametric assumption to be made about the form of the conditional expectation function. This assumption often leads to misspecification error because it incorrectly captures the relationship between the dependent and the explanatory variables for the two groups to be differentiated (here: gender). It is thus likely to result in biased inferences regarding the portion attributable to differences in the distribution of explanatory variables (Barsky et al. 2001) particularly if the range over which the explanatory variables are defined differs for the groups under consideration. We test the extent to which this is the case in our sample of individuals living in marriage or cohabiting by alternatively specifying two reference groups.

The general specification for the Oaxaca decomposition is the following:

$$
\Delta \mu^{(M, W)}=\left[\mu\left(X^{M}\right)-\mu\left(X^{W}\right)\right] \beta^{W}+\mu\left(X^{W}\right)\left[\beta^{M}-\beta^{W}\right]+\left[\mu\left(X^{M}\right)-\mu\left(X^{W}\right)\right]\left[\beta^{M}-\beta^{W}\right]
$$

The first component captures differences due to characteristics, the second due to coefficients (estimated effects) and the third term is the interaction between coefficients and endowments. A discussion of alternative decomposition equations distinguishing different reference groups can be found in appendix A.1.

\subsection{The Juhn, Murphy, \& Pierce decomposition}

The Juhn, Murphy, and Pierce (JMP) (1993) decomposition method extends the Oaxaca decomposition by taking into account the residual distribution. The innovation in the JMP extension is to decompose the "unexplained" or "residual" portion of the gap from the Oaxaca decomposition into price and quantity components. In other words, this technique maintains the component of Oaxaca's decomposition which captures the wealth differential due to the differences in characteristics (endowments), but the second component (due to differences in coefficients) is divided into two effects: one reflects the wealth differential attributable to the respective mean percentile ranks (interpreted as the level of unobserved ability) and the second part captures the differential due to wealth dispersion (interpreted as ability prices or individual characteristic prices), which in this case we could interpret as differences in the wealth function ("discrimination"). (More technical details on the JMP method can be found in Appendix A.2.). 
One should be careful when interpreting these components. The components used as an indicator of the level of unobserved abilities could be due as much to an unobserved characteristic as to the simple omission of explanatory variables. Second, as we are making reference to gender discrimination, this component could reflect the unobservable part of discrimination itself ${ }^{3}$.

\subsection{Nonparametric Methods for Group Comparisons}

In order to avoid making an assumption about the functional form of the conditional expected wealth function we make use of a decomposition technique introduced by DiNardo, Fortin, Lemieux (1996) and used, for example, by Cobb-Clark and Hildebrand (2006). The idea is to use reweighting techniques to identify various counterfactual distributions that allow us to determine the contribution of specific components to the overall gap. In this case, we partition the vector of wealth determinants into four groups: (1) labor market experience, (2) education level, (3) intergenerational characteristics, and (4) demographic characteristics. The first group includes indicators on the current labor market status (self-employed, not in the labor force, whether over 65 years of age). While the second set of variables focuses on the individual's educational attainments, the intergenerational group includes information on the education of the mother and father and on inheritances received in recent years. The final set of variables on demographic characteristics contains indicators of good and bad health, the number of children up to five years of age living in the household, having lived in East Germany in 1989 at the fall of the Wall, migration background, and living with a partner (see Appendix A3 for a more detailed description of the variables)

The specification of the wealth gap as a function of the four groups of variables can be written in the following way:

$$
\begin{aligned}
& \Delta g^{(M, W)}=g^{M}(w)-g^{W}(w)= \\
& =\left[g^{M}(w)-g_{C F}{ }^{1}(w)\right]+\left[g_{C F}{ }^{1}(w)-g_{C F}{ }^{2}(w)\right]+\left[g_{C F}{ }^{2}(w)-g_{C F}{ }^{3}(w)\right]+ \\
& +\left[g_{C F}{ }^{3}(w)-g_{C F}{ }^{4}(w)\right]+\left[g_{C F}{ }^{4}(w)-g^{W}(w)\right]
\end{aligned}
$$

The first component captures the effect of differences in labor market experience distribution on the gender wealth gap; the second component captures the effect of differences between men and women with respect to education; the third effect results from differences in

\footnotetext{
${ }^{3}$ Suen (1997) demonstrates that this decomposition yields biased results if the position in the distribution is not independent of its standard deviation.
} 
intergenerational characteristics; and the fourth effect from demographic differences. The last term refers to the differences between the conditional wealth functions for men and women. (A detailed discussion of the construction of counterfactuals is in Appendix A.3.) Whereas the decomposition following the Blinder-Oaxaca approach focuses on the mean counterfactual, this nonparametric approach examines the distributional counterfactual. The nonparametric approach also allows researchers to avoid making parametric assumptions, which is also important when one is interested in looking at the whole distribution.

Finally, we compare our results obtained from the three different decomposition methods and examine the value added as well as the cross-technique consistency of the respective results.

\section{Results}

\subsection{Descriptive Findings}

In the following section, we investigate gender differences in wealth holdings for adults (17 years and older) only, explicitly considering the composition of the person's household. Basic non-wealth characteristics can be found in Table 1, separately for gender and split by marital status. The rationale for explicitly contrasting these non-wealth characteristics by gender is simply that a possible gender wealth gap may result from differential endowment with certain characteristics rather than from gender per se. This will also be crucial to the gender decomposition analysis that follows.

The women in the sample are slightly older, both overall and in most of the marital status subgroups except married and cohabiting. This reflects that among German couples, men still tend to be about three years older on average than their female partners. Men have higher individual labor income in all groups, but particularly divorced and widowed men. About 7 percentage points more men than women obtained higher education. Among married couples this difference increases to ten percent. Men are more likely to be employed full-time and to be self-employed. Women, on the other hand, are more likely to be employed part-time (13.5\% versus $2 \%$ for men) or not employed (42.5\% versus $25.7 \%$ for men). This employment gap is much more pronounced for married than for cohabiting women. All of these findings can be taken as indications of continued conservative marriage behavior among men and women, confirming the typical pattern of the male-breadwinner model within 
German couples: on average, men are married to younger, less-educated women who work less than full-time, but who-given the relatively low German inheritance taxes-eventually profit from their late husband's wealth accumulation. Strikingly, even in the group of individuals who have never been married, women are less likely to be employed full-time (29.4\% versus $37.4 \%$ for men) and not employed (13.3\% versus $6.6 \%$ ), although there are no substantial differences in education and income. Finally, more women than men recently received an inheritance, but their inheritances are also lower than men's.

Table 2 summarizes wealth holdings among men and women differentiated by marital status. On average, men hold about 30,000 euros more than women. This gap is about 9,000 euros when we look at the median and is present in all household types defined by marital status. Figure 1 presents net worth measures by gender and marital status including 95\% confidence bands: it is only among the widowed and never-married singles that we do not find significant gender wealth gaps. Interestingly, German widows are the wealthiest group among all women, perhaps profiting from the aforementioned inheritance regulations and their longer life expectancy. On the other hand, looking at those currently married, the wealth gap is particularly large with about 47,000 euros. This may come as a surprise: we would expect a more even split among people "sharing their lives." Actually, a substantial part of welfare-oriented research relies on the assumption of pooling and equal sharing of resources, an assumption that is driven by the lack of appropriate data, among other things. The availability of individual microdata in the German SOEP provides us with a unique opportunity to compare individual and aggregated wealth information and thus to examine whether the equal sharing assumption is adequately reflected in the data.

In the following, our analysis focuses on individuals living in marriages or cohabiting partnerships. The wealth variable we use is net worth, which consists of wealth bound in principal residence, other property, financial assets, insurance and private pensions, business assets, tangible assets, and debt. Net worth is top-coded at the $99^{\text {th }}$ percentile (at 925,000 euros) and bottom-coded at the $1^{\text {st }}$ percentile (at -100,000 euros). After establishing some descriptive facts about the wealth gap, we move on to disclose some reasons for these differences including wealth decomposition by gender, based on the methodologies described above. 


\subsection{Some Facts about "Equal Sharing" among Couples in Germany}

The extent to which we observe equal sharing among married and cohabiting couples in Germany is first assessed in a descriptive manner. We do so by defining an indicator variable equal to [-1], [0], and [1] if wealth reported in the household by females is [greater than], [equal to], and [less than] that of males and equal to [9] if no wealth is reported in the household. We will refer to these households as

- "Female-in-charge (F>M),"

- "Equal sharing $(\mathrm{F}=\mathrm{M})$,

- "Male-in-charge $(\mathrm{M}>\mathrm{F})$, , and

- "No wealth", respectively. ${ }^{4}$

In Table 3a we find the breakdown of the different types of "sharing couple-headed households" by wealth quantiles. Only about $15 \%$ of couples experience equal sharing within their households. In $26 \%$ of households, the woman reports holding more wealth than the male counterpart and in nearly $50 \%$ percent of the couple-headed households, men report holding more wealth. There are no substantial differences in this reporting across the wealth distribution. The "male-in-charge" type of household is on average equally present in the $2^{\text {nd }}$ to the $5^{\text {th }}$ quantile. In the bottom wealth quantile, only $20 \%$ of the households are of this type, but this result is driven by the inclusion of couples with no wealth (47\% of those in the lowest quintile or $10 \%$ of the population in couple-headed households).

The average wealth gap, i.e., the absolute difference in wealth holdings by men and women, is 27,967 euros in favor of men (Table 3b). An average gap of this magnitude or larger can be found in households in the top two quantiles of the wealth distribution while in the bottom three quantiles the gap is much lower. In households of the "men-in-charge" type, the gap is about $30 \%$ larger than the respective gap in female-in-charge type of households. This results from the fact that men on average hold more assets in each of the wealth quantiles than their respective female counterpart. In other words, men in female-in-charge households will hold more assets then their female counterpart in male-in-charge households (Table $3 \mathrm{c}$ and $3 \mathrm{~d})$. The one exception is the bottom quantile of the distribution.

\footnotetext{
${ }^{4}$ Obviously, one could define these groups also based on a less strict cut-off, e.g., male and female wealth might be considered "equal" if those values do not deviate by more than $x$ percentage points. Robustness checks have shown that the substantive findings described here do not change in a significant way when choosing various values for $x$.
} 
In order to determine the driving forces behind this phenomenon, we considered various hypotheses. First, we compared the portfolio composition between men and women. A summary of the differences is provided in Table 4. We find that among the married and cohabiting group, men on average hold more wealth of each of the components, but there is a particularly large difference for business assets (Edland \& Kopczuk 2007). The higher prevalence of self-employed males has already been identified in Table 1.

The disparities in the value of owner-occupied homes appear to be less pronounced for married $^{5}$ and cohabiting couples (Table 4) compared to other components of the wealth portfolio. In fact, homeownership seems to exert an equalizing effect given that it is most prevalent among the "equal sharing" households in general (two-thirds of those observations live in owner-occupied housing) as well as in almost every quintile of the wealth distribution (Table 3e).

\subsection{Decomposing the Wealth Gap}

In the following section, we apply three different methods to decompose the gender wealth gap. It must be noted that in this paper, we do not compare men and women within the very same partnership or marriage but rather look at all married or cohabiting men and women, respectively. Nevertheless, this analysis is thought of as a first necessary step towards an investigation of the true intra-partnership wealth distribution.

The standard Blinder-Oaxaca decomposition concentrates on the mean of the variable of interest. Although easy to interpret, the disadvantage of this method is that it requires the assumption of a linear specification, which may bias the decomposition results. For this reason, second, we apply the decomposition method proposed by Juhn, Murphy, and Pierce (1993), which allows us to analyze the gender wealth gap at different points of the distribution. Third, to examine whether factors like labor market experience, educational level, and intergenerational and demographic characteristics affect the dispersion, we adopt the methods presented by DiNardo, Fortin, and Lemieux (1996).

\footnotetext{
${ }^{5}$ Nevertheless, housing equity of married men is about $14 \%$ higher than that of women. This difference is statistically significant.
} 


\subsubsection{Net worth for women and men}

The results presented above suggest that the average wealth difference of about 28,000 euros in households with couples can be explained by many covariates, but only to a certain extent. We examine the effect of these covariates by using regression analysis for women and men separately (see Table 5) ${ }^{6}$. According to these results, once we control for the length of marriage, only full-time labor market experience and permanent income have a significantly different effect for men and women in couple-headed households on the currently accumulated stock of net worth. Controlling for the length of marriage also reverses the magnitude between men and women of the variable indicating having a mother with higher education. Nevertheless, the effect of having a father with higher education remains significantly different for men and women with the effect on women's accumulated wealth being five times stronger than for men. The rest of the covariates have the expected effect. The number of marriages, being an immigrant and having lived in East Germany before 1989 exert a significantly negative effect on net worth. While having high education, being over 65 and having high job autonomy has a positive effect. Having received an inheritance has a significant and strong effect on wealth for both men and women. Finally, it should be noted that - conditional on the choice of covariates - the overall explanatory power of our model is much greater for men than for women: the R-squared of the estimation for men is $29 \%$ vs. only $18 \%$ in the model for women.

\subsubsection{The Blinder-Oaxaca method}

We now turn to the analysis of the gender wealth gap using the Blinder-Oaxaca decomposition approach. The wealth gap between male and female partners depends on three factors: differences in observable characteristics (e.g., education, number of children, life work experience, health, immigrant status, education of parents, inheritance), differences in coefficients across the two groups (e.g., differences in how the characteristics translate into wealth based on the wealth function), and unobservables. Table 6 presents two different sets of results. In the top part of the table, the results treat women as the reference group and in the bottom men are the reference group. In other words, the mean outcome difference can be expressed in the following way:

\footnotetext{
${ }^{6}$ We explore various specifications of the wealth function. These gender-specific regression results can be found in Appendix Tables B.2a for men and B.2b. for women, respectively. The results given in Table 5 correspond to those of specification (8).
} 
$\Delta \mu^{(M, W)}=\left[\mu\left(X^{M}\right)-\mu\left(X^{W}\right)\right] \beta^{W}+\mu\left(X^{M}\right)\left[\beta^{M}-\beta^{W}\right]$,

where women are the reference group; and

$\Delta \mu^{(M, W)}=\left[\mu\left(X^{M}\right)-\mu\left(X^{W}\right)\right] \beta^{M}+\mu\left(X^{W}\right)\left[\beta^{M}-\beta^{W}\right]$,

where men are the reference group. $\mu(\bullet)^{j}$ is the conditional mean function for $j=$ [Woman, Man] and $\beta^{j}$-coefficents for $j$-group and $X^{j}$ characteristics of $j$ group. The explanation of these components can be found in Appendix A.1. According to the results presented in the top panel of Table 6 , close to $70 \%$ of the gap is explained by differences in characteristics between male and female partners. If women had the exact same characteristics as men, their average wealth would increase by about 20,000 euros to almost 100,000 euros. Interestingly enough, if men's characteristics translated into wealth in the same way as women's characteristics do, the average wealth holdings of men would be 125,200 euros instead of 107,761 euros. This is an indication for women deriving "more wealth" from their own characteristics than they would be able to derive if they had the same parameters as men.

Examining the three-fold decomposition according to Blinder-Oaxaca (Table 7) we find that in fact, women's wealth function (the differences in coefficients) compensates for the differences in characteristics almost entirely when the model for men is chosen as the nondiscriminatory model. This could not be seen in the two-fold decomposition. As shown in Table 7, women's average wealth, if they had men's characteristics and wealth functions, would be 98400 euros versus their actual 79,562 euros. The panel shows that although the gap can be decomposed into the portion explained by differences in characteristics and differences in coefficients, the unexplained portion ("Interaction" in Table 7) - that can be interpreted as discrimination - is of similar magnitude to the wealth gap.

\subsubsection{The Juhn-Murphy-Pierce method}

The Blinder-Oaxaca method provided us with the mean outcome difference due to endowments, coefficients, and interactions between these two measures. In the method proposed by Juhn, Murphy, Pierce (1993) and also used by Blau and Kahn (1996), two hypothetical wealth distribution functions are created that allow us to isolate the gender differences due to differences in characteristics, differences in the wealth function between 
men and women, as well as an unexplained portion that is due to unobservable skill between men and women together with the current market value of this unobservable skill measured by equation residuals (see Appendix A.2). We consider three alternative types of measures of these wealth distributions: first, the mean wealth gap that corresponds to the Blinder-Oaxaca decomposition; second, the wealth gap at various percentiles of the distribution; and third, differences in wealth dispersion as measured by the wealth gap between various percentiles.

The results of the mean gap decomposition are given in Table 8. Assuming the male group as the reference group (upper panel), we find that more than 45,000 euros of the gap is due to differences in characteristics suggesting that average women's wealth would exceed that of men's if they both had the same characteristics according to the JMP decomposition. The negative sign on the "gap due to differences in coefficients", i.e., the way women translate their characteristics into wealth, suggests that this has a diminishing effect on the wealth gap. In this non-parametric decomposition method, the unexplained portion is quite small compared to the parametric Oaxaca-Blinder method. The bottom panel confirms the results.

Examining the wealth gap at different points in the distribution, we find, not surprisingly, that it increases as we move up the wealth distribution (see Table 9). It is 18,250 at the median and more then three times as large at the 90th percentile with almost 68,000 euros. Across the distribution, most of the gap stems from the differences in characteristics between men and women, rather than from differences in the way in which-conditional on their characteristics - men and women have accumulated their wealth in the past. Although wealth parameters do matter, particularly at the bottom of the distribution, with increasing wealth there is a distinct increase in the explanatory relevance of the difference in characteristics and a reduction in the role of the differences in the wealth function. The unexplained portion of the wealth also becomes smaller for the wealthier. For the bottom half of the distribution it has a reducing effect on the gap.

Looking at the 90-50 decile ratio (lower panel of Table 9), over half of the differences in wealth dispersion in the two distributions as measured by the wealth gap can be explained by differences in characteristics. As such, in the upper part of the distribution differences in characteristics exert an increasing effect on the wealth gap while according to the results for the 50-10 decile ratio these have a reducing effect on the gap. Over 50\% of the gap also remains unexplained. The differences in the wealth function account for a sizeable part of the 
gap in the lower part of the wealth distribution. This might be interpreted in such a way that the gap among wealthy persons is driven by differences in characteristics between men and women whereas differences in wealth functions are more relevant among the less wealthy.

\subsubsection{The DiNardo-Fortin-Lemieux method}

By using the DiNardo-Fortin-Lemieux approach we avoid making any parametric assumptions about the distribution function and consider comparisons of the whole probability density function. We group the explanatory variables into four groups: (1) labor market experience, (2) education level, (3) intergenerational characteristics, and (4) demographic characteristics. ${ }^{7}$ These factors correspond closely to the list of potential sources of wealth differences among men and women. Similarly to Cobb-Clark \& Hildebrand (2006) and Gibson, Le, and Stillman (2007), the results presented here are obtained by calculating all relevant counterfactuals and then taking the simple average over all possible decompositions. The results for the raw wealth gap correspond to those presented for the JMP decomposition in Table 9, although the decompositions according to DFL differ as they are done sequentially according to the four factor groups (Table 10).

In many cases, the gap is the result of differences in current income and experience in the labor market and not as much related to the other characteristics such as education. The effect of labor market experience is found to be strong at the median and at the top of the distribution, whereas at the bottom of the wealth distribution education plays a somewhat stronger role. For most of the distribution, neither intergenerational nor demographic characteristics add significantly to the explanation of the gender wealth gap. However, a very large part of the gap results from the differences in how men and women have accumulated their wealth - conditional on their characteristics - i.e., differences in their wealth function, which is included in the "unexplained" column of Table 10. This effect is particularly strong in the middle of the wealth distribution [see interquartile range P75-P25], whereas-in line with the results on JMP — at the top of the wealth distribution [see P90-P50] the driving factors are differences in characteristics (here: especially income and labor market experience). Finally, in the lower half of the wealth distribution [see P50-P10] the large and positive effect of income and labor market experience is dampened by a negative impact of the unexplained part.

\footnotetext{
${ }^{7}$ See Appendix A3 for a short description of the indicators used.
} 


\subsubsection{Comparison of results derived from various decomposition techniques}

Both the Oaxaca-Blinder and Juhn-Murphy-Pierce methods confirmed that the average wealth gap results from differences in characteristics between men and women and that the wealth gap would even have been marginally larger if the wealth function for the two groups had been identical. The way women accumulate wealth has a reducing effect on the gap. This was confirmed to be true across the wealth distribution (Table 9). In absolute terms, the unexplained portion of the gap rises as we move up the wealth distribution. In the DiNardo, Fortin, Lemieux method we specify the different factors that could help explain the differences in the wealth gap. Here we find that the observable characteristics play a large role in accounting for the gap (particularly individual income and labor market experience) which is consistent with the Juhn-Murphy-Pierce method only at the top of the distribution. In our analysis, we also check the robustness of the results by excluding the self-employed given that they also accumulate wealth to provide themselves security at a later age. We find our main results remain unchanged with magnitudes of the effects becoming smaller (results available from the authors). ${ }^{8}$

\section{Conclusions}

A main obstacle to the analysis of gender wealth gaps in the empirical literature is the lack of comprehensive wealth information at the individual level (Deere and Doss, 2006). This gap in the literature can be tackled using the 2002 wealth module of the German SOEP, which contains wealth data on about 23,000 individuals. We find clear empirical indications of a significant gender wealth gap of about 30,000 euros, which amounts to almost 50,000 euros for partners in married couples. We find that overall only about $15 \%$ of all couples have equal sharing within their households. In $26 \%$ of households, the woman reports having more wealth than her male partner and in nearly $50 \%$ men report more wealth.

Using various decomposition methods (Oaxaca-Blinder, Juhn-Murphy-Pierce, and DiNardo, Fortin, Lemieux) we find a robust picture of the wealth gap being mostly driven by

\footnotetext{
${ }^{8}$ As women's labor market experience has changed across cohorts it is plausible that it's effect on the wealth gap varies, as well. As a check, we address this issue by performing the DFL decomposition on a sample of younger and older households. The conclusions obtained from the whole sample remain valid in this case although the raw gap is lower for the younger cohorts and understandably, the role of intergenerational factors is also smaller for this group. The effect of education is relatively stronger for the older population (results available from authors).
} 
differences in characteristics between men and women. By far the most important factor is the individual's own income and labor market experience particularly for the bottom and top of the wealth distribution. However, this finding can only be shown with the non-parametric JMP and DFL methods due to the mean-orientation of the parametric Oaxaca-Blinder technique. Differences for those in the middle of the distribution seem to appear to be mostly driven by the way women transform their characteristics into wealth, i.e., the wealth function.

Future research will have to focus more closely on wealth differentials between malefemale couples living in the same household. To shed more light on the intra-partnership wealth variation, we also need to control for gender-specific marriage patterns, and consequently, to analyze the wealth gap as a function of within-partnership variation with respect to age, education, income, employment status, etc. Such an approach, however, demands extensive microdata as well as the consideration of the institutional framework, especially in Germany with its well developed public pension system. As shown above, individual wealth holdings depend crucially on employment status: self-employed individuals who are not covered by the statutory public pension scheme have to invest in private old age provisions. Consequently, we find this group to be much better off in our wealth measure, which ignores an individual's public pension entitlements. Obviously, within partnerships, wealth holdings as well as plans for further accumulation will vary by both partner's employment status and consequently by whether or not a person is accumulating their own public pension entitlements. Due to the prominence of the male breadwinner model in Germany, the effect of considering individual pension entitlements on the intra-partnership wealth gap will very likely increase. The analyses and results presented in this paper based on financial and real assets may be seen as a first and necessary step towards achieving a more comprehensive understanding of the gender wealth gap. 


\section{References}

Allmendinger, J.; Gartner, H.; Ludwig-Mayerhofer, W. (2006): The allocation of money in couples: the end of inequality? Zeitschrift für Soziologie, 35 (3): 212-226.

Bajtelsmit, V. and Van Derhei, J. (1997): Risk Aversion and Pension Investment Choices. In: Gordon, M.S. et al (eds.): Positioning Pensions for the Twenty-First Century. University of Pennsylvania Press, Philadelphia.

Bardasi, E. and Gornick, J.C. (2008). Working for Less? Women's Part-Time Wage Penalties across Countries, Feminist Economics. 14(1): 37-72.

Barsky, R.; Bound, J.; Charles, K. and Lupton, J. (2001): Accounting for the Black-White Wealth Gap: A Nonparametric Approach. NBER Working Paper \#8466.

Berger, E. and Denton, M. (2004): The Interplay Between Women's Work Histories and Financial Planning for Later Life. Canadian Journal on Aging, 23(Supplement1): 99-113.

Blau, F.D. and Kahn, L.M. (1996): International Differences in Male Wage Inequality: Institutions versus Market Forces. Journal of Political Economy, 104(4): 791-837.

Blau, F.D. and Kahn, L.M. (1997): Swimming Upstream: Trends in the Gender Wage Differential in the 1980s. Journal of Labor Economics, 15: 1-42.

Blau, F.D. and Kahn, L.M. (2000): Gender Differences in Pay. Journal of Economic Perspectives, 14: 75-99.

Blinder, A.S. (1973): Wage Discrimination: Reduced Form and Structural Estimates. Journal of Human Resources, 8: 436-455.

Blumberg, R.L. (1988): Income under female versus male control: Hypothesis from a theory of gender stratification and data from the third world. Journal of Family Issues, 9:51-84.

Bolin, K. and A. Pålsson (2001) Male and Female Wealth: the Importance of the Family Structure. Prepared for the $21^{\text {st }}$ Arne Ryde Symposium on Non-Human Wealth and Capital Accumulation, Department of Economics, Lund University, Lund, Sweden, August 23-25, 2001

Brush, C.G., Carter, N.M.; Greene, P.G.; Hart, M.H. and Gatewood, E. (2002): The Role of Social Capital and Gender in Linking Financial Suppliers and Entrepeneurial Firms: A Framework for Future Research. Venture Capital, 4(4): 305-23.

Cobb-Clark D. and Hildebrand, V. (2006): The Wealth of Mexican Americans. The Journal of Human Resources, 41(4): 841-873.

Deere, C.D. and Doss, C.R. (2006): The gender asset gap: What do we know and why does it matter? Feminist Economics, 12(1-2): 1-50

DiNardo, J.; Fortin, N.M. and Lemieux, T. (1996): Labour Market Institutions and the Distribution of Wages, 1973-1992: A Semiparametric Approach. Econometrica, 64(5): 1001-1044.

Edland, L. and W. Kopczuk (2007) "Women, Wealth and Mobility," unpublished manuscript

Frick, J.R.; Grabka, M.M. and Sierminska, E.M. (2007): Representative Wealth Data for Germany from the German SOEP: The Impact of Methodological Decisions around Imputation and the Choice of the Aggregation Unit. DIW discussion paper no. 562, Berlin, March.

Frick, J.R.; Grabka, M.M. and Marcus, J. (2007): Editing and Multiple Imputation of Item-Non-Response in the 2002 Wealth Module of the German Socio-Economic Panel (SOEP). SOEPpapers on Multidisciplinary Panel Data Research at DIW Berlin, No. 18/2007, Berlin: DIW Berlin.

Friedman, M. (1957): A Theory of the Consumption Function. Princeton University Press. Princeton.

Gibson, J.; Le, T. and Scobie, G. (2006): Household Bargaining over Wealth and the Adequacy of Women's Retirement Incomes in New Zealand. Feminist Economics, 12(1-2): 221-246.

Gibson, J.; Le, T. and Stillman, S. (2007): What Explains the Wealth Gap Between Immigrants and the New Zealand Born? Motu Working Paper No. 07-12, September 2007.

Haddad, L. and Kanbur, R. (1990): How serious is the neglect of intra-household inequality? Economic Journal, 100: $866-881$.

Harbury, C.D. and Hitchens, D.M.W.N. (1977): Women, Wealth and Inheritance. The Economic Journal, 87(345): 124-131. 
Hinz, R.P., McCarthy, D.D. and Turner, J.A. (1997): Are women more conservative investors?: gender differences in participant-directed pension investments. Positioning pensions for the twenty-first century. Gordon, M.S.; Mitchell, O.S. and Twinney, M.M. Eds. Philadelphia: University of Pennsylvania Press, 91103.

Jenkins, S.P. and Van Kerm, P. (forthcoming), The Measurement of Economic Inequality, in Nolan, B., Salverda, W., and Smeeding, T. (Eds), The Oxford Handbook of Economic Inequality, Oxford University Press, Oxford.

Jianakopolos, N.A. and Bernasek, A. (1998). Are Women More Risk Averse? Economic Inquiry, 36: 620-30.

Juhn, C.; Murphy, K.M. and Pierce, B. (1993): Wage Inequality and the Rise in Returns to Skill. Journal of Political Economy, 101(3): 410-442.

Kimball, M.S. (1990): Precautionary Saving in the Small and in the Large. Econometrica, 58(1), 53-73.

Ladd, H.F. (1998): Evidence on Discrimination in Credit Markets. Journal of Economic Perspectives, 1: 223234.

Levine, P.B., Mitchell, O.S. and Moore, J.F. (2000): Women on the Verge of Retirement: Predictors of Retiree Well-Being. In: Mitchell, O.S. Hammond, P.B. and Rappaport, A.M. (Eds): Forecasting Retirement Needs and Retirement Wealth. Philadelphia: University of Pennsylvania Press., 167-207.

Lupton, J.P. and Smith, J.P. (2003): Marriage, Assets and Savings. In: Grossbard-Shechtman, S.A. (Ed): Marriage and the Economy: Theory and Evidence from Advanced Industrial Societies. Cambridge: Cambridge University Press, 129-152.

Mohanty, L. (2004): The Determinants of Wealth after Divorce in the United States. Paper presented at the Workshop on Women and the Distribution of Wealth, Yale University, November 12-13. New Haven, CT.

Modigliani, F. and Brumberg, R. (1954). Utility analysis and the consumption function: An interpretation of cross-section data. In Kurihara, K. (Ed.): Post Keynesian Economics,. Rutgers University Press: New Brunswick, NJ, 388- 336.

Moore, Q. and Shierholz, H. (2004): Why Did the Convergence of Male and Female Wages Slow During the 1990s? University of Michigan unpublished manuscript.

O’Neill, J. (2003). The Gender Gap in Wages, circa 2000. American Economic Review, 93(2): 309-14.

Oaxaca, R. (1973): Male-Female Wage Differentials in Urban Labor Markets. International Economic Review, 14: 693-709.

Pahl, J. (2001): Couples and their money: theory and practice in personal finances. In: R. Sykes, Bochel, Ch. and Ellison, N. (Eds.): Social Policy Review 13. Developments and Debates 2000-2001, Bristol: Policy Press: 17-38.

Phipps, S.A. and Burton, A. (1994): Sharing Within Families: Implications for the Distribution of Individual Well-Being in Canada. Department of Economics Working Paper 94-07. Halifax, NS: Dalhousie University.

Phipps, S. and Burton, P. (1995): Sharing within families: implications for the measurement of poverty among individuals in Canada. Canadian Journal of Economics, 28(1): 177 - 204.

Riphahn, R.T. and Serfling, O. (2005): Item Non-response on Income and Wealth Questions. Empirical Economics, 30(2): 521-538.

Robinson, J.K. (2002): Race, Gender, and Familial Status: Discrimination in One U.S. Mortgage Lending Market. Feminist Economics, 8(2): 63-85.

Schmidt, L. and Sevak, P. (2006): Gender, Marriage, and Asset Accumulation in the United States. Feminist Economics, 12 (1-2): 139-166.

Sedo, S.A. and Kossoudji, S.A. (2004): Rooms of One's Own: Gender, Race and Homeownership as Wealth Accumulation in the United States. IZA DP No. 1397. Bonn, Germany: Institute for the Study of Labor (IZA). November.

Sen, A.K. (1990): Gender and Cooperative Conflicts. In: Tinker, I. (ed.): Persistent Inequalities: Women and World Development, New York: Oxford University Press, 123- 149.

Sierminska, E., A. Brandolini and T.M. Smeeding (2006): “Comparing wealth distribution across rich countries: First results from the Luxembourg Wealth Study" Luxembourg Wealth Study Working Paper No.1, (2006)

Suen, W. (1997): Decomposing wage residuals: Unmeasured skill or statistical artifact? Journal of Labor Economics, 15(3): 555-566.

Wagner, G.G., Frick, J.R., Schupp, J. (2007): The German Socio-Economic Panel Study (SOEP) - Evolution, Scope and Enhancements. Schmoller's Jahrbuch - Journal of Applied Social Science Studies 127(1): 139ff. 
Warren, T. (2006): Moving beyond the gender wealth gap: On gender, class, ethnicity, and wealth inequalities in the United Kingdom. Feminist Economics, 12(1\&2): 195 - 219.

Warren, T.; Rowlingson, K. and Whyley, C. (2001): Female finances: Gender Wage Gaps and Gender Assets Gaps. Work. Employment and Society, 15: 465-488.

Wedgwood, J. (1939): The Economics of Inheritance. Penguin Books (reprint).

Woolley, F. (1993): The Feminist Challenge to Neoclassical Economics. Cambridge Journal of Economics, 17: 485-500.

Yamokosi, A. and Keister, L.A. (2006) The Wealth of Single Women: Marital Status and Parenthood in the Asset Accumulation of Young Baby Boomers in the United States. Feminist Economics, 12 (1-2): 167-194.

Zagorsky, J.L. (1999): Young Baby Boomers' Wealth. Review of Income and Wealth, 45(2): 135-156.

Zeldes, S. (1989): Optimal consumption with stochastic income: Deviations from certainty equivalence. Quarterly Journal of Economics, 104: 275-298. 


\section{Tables and Figures}

Table 1: Basic non-wealth characteristics by gender and marital status, Germany 2002

\begin{tabular}{|c|c|c|c|c|c|c|c|c|c|c|c|c|c|}
\hline & $\begin{array}{l}\text { Male } \\
\text { TOTAL }\end{array}$ & $\begin{array}{l}\text { Male } \\
\text { married }\end{array}$ & $\begin{array}{l}\text { Male } \\
\text { cohabit. }\end{array}$ & $\begin{array}{l}\text { Male } \\
\text { single - } \\
\text { divorced/ } \\
\text { separated }\end{array}$ & $\begin{array}{l}\text { Male } \\
\text { single - } \\
\text { widowed }\end{array}$ & $\begin{array}{l}\text { Male } \\
\text { single - } \\
\text { never } \\
\text { married }\end{array}$ & $\begin{array}{l}\text { Female } \\
\text { TOTAL }\end{array}$ & $\begin{array}{l}\text { Female } \\
\text { married }\end{array}$ & $\begin{array}{l}\text { Female } \\
\text { cohabit. }\end{array}$ & $\begin{array}{l}\text { Female } \\
\text { single }- \\
\text { divorced/ } \\
\text { separated }\end{array}$ & $\begin{array}{l}\text { Female } \\
\text { single - } \\
\text { widowed }\end{array}$ & $\begin{array}{l}\text { Female } \\
\text { single - } \\
\text { never } \\
\text { married }\end{array}$ & TOTAL \\
\hline \multicolumn{14}{|l|}{ "Demographics } \\
\hline Age (in years) & 47.1 & 53.3 & 39.2 & 50.2 & 70.7 & 30.5 & 49.4 & 50.2 & 36.9 & 53.2 & 73.9 & 32.0 & 48.3 \\
\hline$\%$ Immigrant & 11.8 & 14.3 & 5.1 & 12.0 & 6.5 & 8.6 & 11.2 & 14.1 & 5.5 & 10.7 & 8.7 & 7.5 & 11.5 \\
\hline $\begin{array}{l}\% \text { Foreign } \\
\text { citizenship }\end{array}$ & 8.1 & 9.7 & 3.1 & 7.5 & 0.8 & 7.2 & 6.7 & 9.0 & 2.8 & 5.7 & 2.6 & 5.2 & 7.4 \\
\hline Household size & 2.60 & 2.93 & 2.49 & 1.24 & 1.19 & 2.37 & 2.47 & 2.93 & 2.48 & 1.77 & 1.25 & 2.35 & 2.53 \\
\hline $\begin{array}{l}\text { Number of children } \\
<17\end{array}$ & 0.47 & 0.64 & 0.39 & 0.07 & 0.04 & 0.25 & 0.47 & 0.64 & 0.38 & 0.44 & 0.04 & 0.37 & 0.47 \\
\hline \multicolumn{14}{|l|}{ Income } \\
\hline $\begin{array}{l}\text { Equiv. Annual Post- } \\
\text { Govt. Income } \\
\text { (mean) }\end{array}$ & 20,788 & 21,877 & 20,375 & 20,531 & 17,613 & 18,712 & 18,915 & 21,355 & 19,086 & 14,182 & 14,782 & 17,091 & 19,790 \\
\hline $\begin{array}{l}\text { Relative Post-Govt. } \\
\text { income position }\end{array}$ & 105 & 111 & 103 & 104 & 89 & 95 & 96 & 108 & 96 & 72 & 75 & 86 & 100 \\
\hline $\begin{array}{l}\text { Individual Annual } \\
\text { Labor Income } \\
\text { (mean) }\end{array}$ & 22,952 & 26,139 & 24,459 & 25,862 & 5,272 & 15,975 & 10,019 & 9,827 & 17,092 & 12,714 & 2,249 & 11,711 & 16,063 \\
\hline $\begin{array}{l}\text { Relative labor } \\
\text { income position }\end{array}$ & 143 & 163 & 152 & 161 & 33 & 99 & 62 & 61 & 106 & 79 & 14 & 73 & 100 \\
\hline \multicolumn{14}{|l|}{ Education } \\
\hline low (isced $=0.1 .2$ ) & 17.6 & 13.1 & 9.4 & 15.3 & 19.1 & 32.1 & 26.1 & 22.0 & 17.0 & 24.3 & 41.1 & 33.2 & 22.1 \\
\hline middle (isced $=3$ ) & 47.9 & 47.7 & 53.2 & 49.3 & 59.2 & 44.9 & 47.9 & 51.2 & 47.0 & 45.3 & 45.7 & 40.9 & 47.9 \\
\hline $\begin{array}{l}\text { (higher) vocational } \\
\text { (isced=4.5) }\end{array}$ & 13.1 & 13.7 & 17.6 & 11.2 & 10.5 & 10.5 & 11.4 & 11.2 & 17.2 & 12.5 & 6.7 & 12.2 & 12.2 \\
\hline $\begin{array}{l}\text { higher eduation } \\
\text { (isced=6) }\end{array}$ & 21.4 & 25.5 & 19.8 & 24.2 & 11.2 & 12.4 & 14.6 & 15.7 & 18.8 & 17.9 & 6.5 & 13.7 & 17.8 \\
\hline
\end{tabular}

... contd. 
... contd.

\begin{tabular}{|c|c|c|c|c|c|c|c|c|c|c|c|c|c|}
\hline & $\begin{array}{l}\text { Male } \\
\text { TOTAL }\end{array}$ & $\begin{array}{l}\text { Male } \\
\text { married }\end{array}$ & $\begin{array}{l}\text { Male } \\
\text { cohabit. }\end{array}$ & $\begin{array}{l}\text { Male } \\
\text { single - } \\
\text { divorced/ } \\
\text { separated }\end{array}$ & $\begin{array}{l}\text { Male } \\
\text { single - } \\
\text { widowed }\end{array}$ & $\begin{array}{l}\text { Male } \\
\text { single - } \\
\text { never } \\
\text { married }\end{array}$ & $\begin{array}{l}\text { Female } \\
\text { TOTAL }\end{array}$ & $\begin{array}{l}\text { Female } \\
\text { married }\end{array}$ & $\begin{array}{l}\text { Female } \\
\text { cohabit. }\end{array}$ & $\begin{array}{l}\text { Female } \\
\text { single - } \\
\text { divorced/ } \\
\text { separated }\end{array}$ & $\begin{array}{l}\text { Female } \\
\text { single - } \\
\text { widowed }\end{array}$ & $\begin{array}{l}\text { Female } \\
\text { single - } \\
\text { never } \\
\text { married }\end{array}$ & "TOTAL \\
\hline \multicolumn{14}{|l|}{$\begin{array}{l}\text { Labor market } \\
\text { status }\end{array}$} \\
\hline FT employed & 42.6 & 44.9 & 52.7 & 44.5 & 5.9 & 37.4 & 20.6 & 17.0 & 44.6 & 27.4 & 3.5 & 29.4 & 30.9 \\
\hline PT employed & 2.0 & 1.5 & 2.4 & 0.7 & 1.3 & 3.5 & 13.5 & 19.3 & 12.7 & 12.4 & 3.6 & 4.6 & 8.1 \\
\hline self employed & 7.3 & 7.7 & 10.8 & 9.4 & 4.8 & 4.8 & 2.7 & 3.1 & 2.5 & 3.7 & 0.8 & 2.6 & 4.9 \\
\hline not employed & 25.7 & 33.0 & 10.5 & 22.4 & 83.8 & 6.6 & 42.5 & 46.0 & 15.9 & 35.9 & 88.0 & 13.3 & 34.7 \\
\hline unemployed & 6.6 & 5.1 & 9.2 & 13.9 & 1.9 & 7.8 & 5.7 & 4.8 & 8.9 & 12.5 & 1.6 & 6.4 & 6.1 \\
\hline civil servants & 5.2 & 6.0 & 5.8 & 7.2 & 0.9 & 3.1 & 2.7 & 3.1 & 3.8 & 2.9 & 0.6 & 2.5 & 3.9 \\
\hline in voc. training & 8.3 & 0.6 & 5.3 & 0.8 & 0.1 & 31.6 & 7.5 & 0.7 & 7.9 & 2.0 & 0.3 & 36.5 & 7.9 \\
\hline irregular work & 2.4 & 1.3 & 3.4 & 1.1 & 1.3 & 5.2 & 4.8 & 6.1 & 3.7 & 3.4 & 1.7 & 4.8 & 3.7 \\
\hline Total & 100.0 & 100.0 & 100.0 & 100.0 & 100.0 & 100.0 & 100.0 & 100.0 & 100.0 & 100.0 & 100.0 & 100.0 & 100.0 \\
\hline \multicolumn{14}{|l|}{$\begin{array}{l}\text { Regional } \\
\text { characteristics }\end{array}$} \\
\hline$\%$ in East Germany & 19.0 & 17.9 & 23.2 & 23.5 & 18.7 & 19.0 & 18.7 & 17.7 & 22.7 & 19.6 & 18.6 & 19.2 & 18.8 \\
\hline$\%$ City $(>500.000)$ & 15.1 & 12.6 & 20.2 & 22.6 & 13.6 & 17.6 & 16.4 & 13.0 & 19.7 & 22.6 & 18.2 & 20.6 & 15.8 \\
\hline \multicolumn{14}{|l|}{ Inheritance } \\
\hline $\begin{array}{l}\text { \% recent inheritance } \\
\text { (since 1997) }\end{array}$ & 4.1 & 4.0 & 5.2 & 3.3 & 7.1 & 3.9 & 4.8 & 4.6 & 7.3 & 3.6 & 5.5 & 4.6 & 4.5 \\
\hline $\begin{array}{l}\text { Amount inheritance } \\
(\text { median, in } €)\end{array}$ & 15,339 & 15,339 & 20,452 & 20,452 & 25,565 & 35,790 & 12,782 & 12,782 & 10,226 & 12,782 & 15,339 & 12,782 & 15,339 \\
\hline $\begin{array}{l}\% \text { expected } \\
\text { inheritance }\end{array}$ & 15.4 & 12.9 & 21.3 & 11.4 & 3.9 & 21.9 & 11.8 & 12.3 & 18.1 & 10.3 & 2.2 & 15.3 & 13.5 \\
\hline $\begin{array}{l}\text { n per implicate } \\
\text { (unweighted) }\end{array}$ & 12,199 & 7,423 & 977 & 521 & 252 & 2,339 & 12,756 & 7,461 & 1,048 & 800 & 1,013 & 1,927 & 24,955 \\
\hline $\begin{array}{l}\mathrm{N} \text { in } 1.000 \\
\text { (weighted) }\end{array}$ & 31,391 & 18,353 & 2,701 & 2,005 & 958 & 7,375 & 35,777 & 18,651 & 3,015 & 3,213 & 4,741 & 6,156 & 67,168 \\
\hline $\begin{array}{l}\text { Gender specific } \\
\text { Population Share, \% }\end{array}$ & 100.0 & 58.5 & 8.6 & 6.4 & 3.1 & 23.5 & 100.0 & 52.1 & 8.4 & 9.0 & 13.3 & 17.2 & -- \\
\hline $\begin{array}{l}\text { Overall Population } \\
\text { Share in \% }\end{array}$ & 46.7 & 27.3 & 4.0 & 3.0 & 1.4 & 11.0 & 53.3 & 27.8 & 4.5 & 4.8 & 7.1 & 9.2 & 100.0 \\
\hline
\end{tabular}

Source: SOEP 2002. 
Table 2: Net wealth by gender and marital status', Germany 2002

\begin{tabular}{|c|c|c|c|c|c|c|c|c|c|c|c|c|}
\hline & \multicolumn{6}{|c|}{ Male } & \multicolumn{6}{|c|}{ Female } \\
\hline & Total & Married & $\begin{array}{l}\text { Coha- } \\
\text { biting }\end{array}$ & $\begin{array}{l}\text { Divor- } \\
\text { ced }\end{array}$ & $\begin{array}{l}\text { Wido- } \\
\text { wed }\end{array}$ & Single & Total & Married & $\begin{array}{l}\text { Coha- } \\
\text { biting }\end{array}$ & $\begin{array}{l}\text { Divor- } \\
\text { ced }\end{array}$ & $\begin{array}{l}\text { Wido- } \\
\text { wed }\end{array}$ & Single \\
\hline \multicolumn{13}{|l|}{ Net wealth (nominal) } \\
\hline mean, in $€$ & 97,378 & 130,648 & 61,636 & 63,570 & 120,142 & 33,908 & 67,373 & 83,722 & 35,425 & 33,761 & 102,192 & 24,214 \\
\hline median, in $€$ & 19,757 & 53,994 & 6,500 & 5,170 & 26,707 & 414 & 10,045 & 35,094 & 4,057 & 1,040 & 12,940 & 0 \\
\hline $\begin{array}{l}\text { relative wealth } \\
\text { position }\end{array}$ & 120 & 161 & 76 & 78 & 148 & 42 & 83 & 103 & 44 & 41 & 126 & 30 \\
\hline$\%$ share wealth $=0$ & 21.3 & 11.9 & 22.7 & 23.9 & 21.5 & 43.2 & 27.0 & 17.9 & 27.6 & 39.8 & 26.5 & 47.8 \\
\hline$\%$ share wealth $<0$ & 6.4 & 5.4 & 9.0 & 17.4 & 0.2 & 5.8 & 4.5 & 4.3 & 9.2 & 7.9 & 1.1 & 3.6 \\
\hline \multicolumn{13}{|l|}{ Quintile shares } \\
\hline bottom & -1.6 & -1.4 & -2.2 & -5.8 & 0.0 & -1.7 & -2.1 & -2.4 & -7.0 & -2.6 & -0.2 & -1.8 \\
\hline 2 & 0.5 & 2.0 & 0.3 & 0.0 & 1.2 & 0.0 & 0.3 & 1.4 & 0.0 & 0.0 & 0.5 & 0.0 \\
\hline 3 & 4.5 & 8.5 & 2.6 & 2.0 & 6.9 & 0.7 & 3.8 & 8.8 & 2.4 & 1.2 & 3.8 & 0.5 \\
\hline 4 & 17.7 & 19.0 & 10.6 & 13.1 & 23.4 & 7.3 & 19.8 & 23.1 & 10.6 & 10.6 & 22.6 & 6.3 \\
\hline top & 78.9 & 71.9 & 88.8 & 90.8 & 68.4 & 93.6 & 78.3 & 69.1 & 93.9 & 90.8 & 73.4 & 95.0 \\
\hline \multicolumn{13}{|l|}{ Inequality } \\
\hline Gini* & 0.749 & 0.661 & 0.843 & 0.899 & 0.675 & 0.894 & 0.775 & 0.699 & 0.948 & 0.875 & 0.715 & 0.911 \\
\hline $\mathrm{GE}(2)^{*}$ & 1.57 & 1.07 & 2.79 & 2.74 & 1.05 & 4.35 & 1.93 & 1.45 & 4.15 & 3.24 & 1.31 & 5.12 \\
\hline p90/p50 & 11.69 & 5.14 & 25.02 & 33.96 & 11.50 & 169.65 & 18.01 & 5.86 & 24.64 & 99.40 & 19.67 & n.d. \\
\hline $\mathrm{p} 75 / \mathrm{p} 50$ & 5.40 & 2.68 & 6.64 & 9.77 & 5.67 & 35.40 & 8.77 & 3.19 & 6.01 & 22.97 & 10.17 & n.d. \\
\hline $\begin{array}{l}\text { n per implicate } \\
\text { (unweighted) }\end{array}$ & 12,199 & 7,423 & 977 & 521 & 252 & 2,339 & 12,756 & 7,461 & 1,048 & 800 & 1,013 & 1,927 \\
\hline $\mathrm{N}$ in 1.000 (weighted) & 31,391 & 18,353 & 2,701 & 2,005 & 958 & 7,375 & 35,777 & 18,651 & 3,015 & 3,213 & 4,741 & 6,156 \\
\hline $\begin{array}{l}\text { Gender specific Pop. } \\
\text { Share, } \%\end{array}$ & 100.0 & 58.5 & 8.6 & 6.4 & 3.1 & 23.5 & 100.0 & 52.1 & 8.4 & 9.0 & 13.3 & 17.2 \\
\hline Overall Pop. Share, \% & 46.7 & 27.3 & 4.0 & 3.0 & 1.4 & 11.0 & 53.3 & 27.8 & 4.5 & 4.8 & 7.1 & 9.2 \\
\hline
\end{tabular}

* $1 \%$ Topcoding (p99[implicate A]=925.000)

Note: Calculations are based on multiply imputated data

${ }^{1}$ Each cell gives the estimate derived from multiply imputed data together with the upper and lower bound of a $95 \%$ confidence interval (in italics).

Source: SOEP 2002. 
Figure 1: Net worth ${ }^{1}$ by martial status and gender, Germany 2002

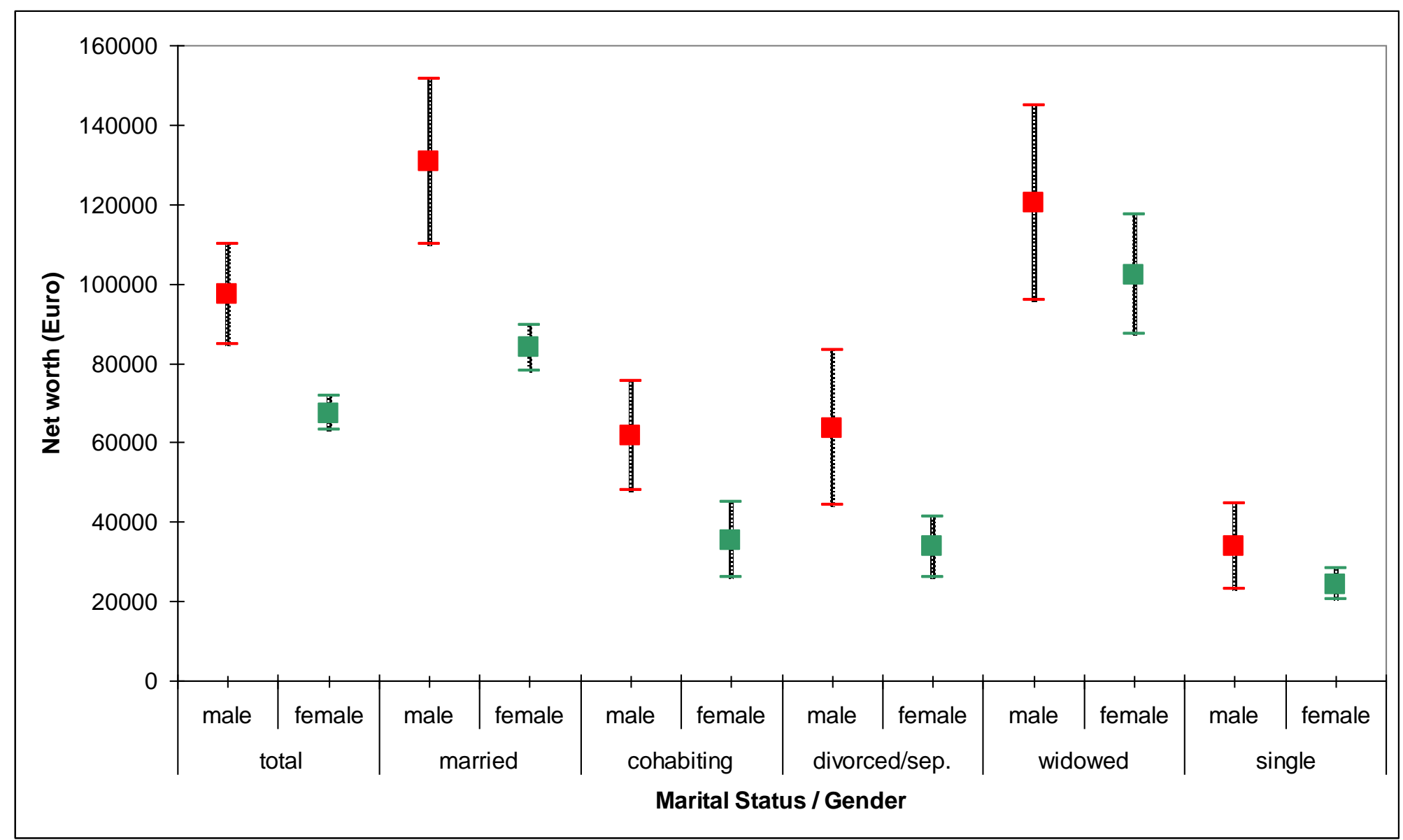

${ }^{1}$ Estimates derived from multiply imputed data together with a 95\% confidence interval (mean in 2002 euros).

Source: German SOEP 2002; authors' calculations. 
Table 3a: Distribution of different couple-headed household sharing type by wealth quantiles

\begin{tabular}{lr|rrrr|r}
\hline $\begin{array}{l}\text { Wealth } \\
\text { quantile }\end{array}$ & \multicolumn{5}{|c|}{ Sharing Type } & \\
\hline & 1 & 22.1 & 8.8 & 22.0 & 47.1 & 100 \\
& 2 & 30.7 & 14.8 & 54.5 & & 100 \\
& 3 & 28.6 & 20.5 & 50.9 & & 100 \\
& 4 & 25.8 & 17.4 & 56.8 & & 100 \\
& 5 & 25.0 & 14.4 & 60.7 & & 100 \\
\hline \multicolumn{2}{l|}{ Total } & 26.4 & 15.1 & 48.8 & 9.7 & 100 \\
\hline \hline
\end{tabular}

Note:

-1 = Female-in-charge: Woman's wealth exceeds man's wealth in a couple-headed household

$0=$ Equal sharing among partners in a couple-headed household

$1=$ Male-in-charge: Man's wealth exceeds woman's wealth in a couple-headed household

$9=$ No wealth in a couple-headed household

Source: SOEP 2002.

Source: SOEP $20 \overline{\overline{02}}$

Table 3b: Average wealth gap in couple-headed household by sharing type and wealth quantiles

\begin{tabular}{|c|c|c|c|c|c|}
\hline \multirow{2}{*}{$\begin{array}{c}\text { Wealth } \\
\text { quantile }\end{array}$} & \multicolumn{4}{|c|}{ Sharing Type } & \multirow[b]{2}{*}{ Total } \\
\hline & -1 & 0 & 1 & 9 & \\
\hline 1 & -16039 & 0 & 10396 & -15 & -1261 \\
\hline 2 & -9370 & 0 & 12836 & & 4111 \\
\hline 3 & -38344 & 0 & 43569 & & 11209 \\
\hline 4 & -67742 & 0 & 80748 & & 28374 \\
\hline 5 & -160458 & 0 & 227005 & & 97689 \\
\hline Total & -56799 & 0 & 88113 & -15 & 27967 \\
\hline
\end{tabular}

Table 3c: Average wealth of female in couple-headed household by sharing type and wealth quantiles

\begin{tabular}{c|cccc|c}
\hline \multirow{2}{*}{$\begin{array}{c}\text { Wealth } \\
\text { quantile }\end{array}$} & \multicolumn{4}{|c|}{ Sharing Type } & \\
\cline { 2 - 6 } & -1 & 0 & 1 & 9 & Total \\
\hline 1 & 2459 & -8498 & -9436 & 7 & -2280 \\
2 & 15290 & 10815 & 4682 & & 8850 \\
3 & 66688 & 50172 & 27580 & & 43396 \\
4 & 139964 & 105425 & 68431 & & 93331 \\
5 & 346941 & 298062 & 165269 & & 229689 \\
\hline Total & 111309 & 95395 & 62935 & 7 & 74480 \\
\hline \hline
\end{tabular}

Source: SOEP $20 \overline{\overline{02} \text {. }}$ 
Table 3d: Average wealth of male in couple-headed household by sharing type and wealth quantiles

Source: SOEP $20 \overline{\overline{02} \text {. }}$

\begin{tabular}{|c|c|c|c|c|c|c|}
\hline \multirow{2}{*}{\multicolumn{2}{|c|}{$\begin{array}{l}\text { Income } \\
\text { quantile }\end{array}$}} & \multicolumn{4}{|c|}{ Sharing Type } & \multirow[b]{2}{*}{ Total } \\
\hline & & -1 & 0 & 1 & 9 & \\
\hline & 1 & -13580 & -8498 & 960 & -7 & -3541 \\
\hline & 2 & 5919 & 10815 & 17518 & & 12961 \\
\hline & 3 & 28344 & 50172 & 71149 & & 54605 \\
\hline & 4 & 72222 & 105425 & 149180 & & 121705 \\
\hline & 5 & 186483 & 298062 & 392273 & & 327378 \\
\hline Total & & 54509 & 95395 & 151048 & -7 & 102447 \\
\hline
\end{tabular}

Table 3e: Prevalance of homeowners by sharing type and wealth quantiles

\begin{tabular}{lr|rrrr|r}
\hline \multirow{2}{*}{\begin{tabular}{c}
\multirow{2}{*}{$\begin{array}{l}\text { Wealth } \\
\text { quantile }\end{array}$} \\
\cline { 2 - 7 }
\end{tabular}} & \multicolumn{5}{|c|}{ Sharing Type } & \\
\hline & 1 & -1 & 0 & 1 & 9 & Total \\
\hline & 2 & 0.08 & 0.07 & 0.07 & 0.01 & 0.04 \\
& 3 & 0.44 & 0.77 & 0.64 & & 0.11 \\
& 4 & 0.63 & 0.99 & 0.90 & & 0.61 \\
& 5 & 0.70 & 0.97 & 0.92 & & 0.85 \\
\hline Total & 0.38 & 0.67 & 0.60 & 0.01 & 0.87 \\
\hline \hline
\end{tabular}

Source: SOEP $20 \overline{\overline{02} \text {. }}$

Table 4: Relative gender wealth gap (men/women) based on average wealth holdings by marital status, Germany 2002

\begin{tabular}{|l|c|ccccc|}
\hline Wealth Component & TOTAL & Married & Cohabiting & $\begin{array}{c}\text { Single }- \\
\text { divorced/ } \\
\text { separated }\end{array}$ & $\begin{array}{c}\text { Single }- \\
\text { widowed }\end{array}$ & $\begin{array}{c}\text { Single - } \\
\text { never } \\
\text { married }\end{array}$ \\
\hline Housing & $\mathbf{1 . 0 9}$ & $\mathbf{1 . 1 4}$ & 1.17 & 1.39 & 1.22 & 1.03 \\
Other Property & $\mathbf{1 . 4 6}$ & $\mathbf{1 . 5 4}$ & 2.75 & 1.73 & 0.57 & 1.34 \\
Financial assets & $\mathbf{1 . 3 6}$ & $\mathbf{1 . 5 4}$ & 0.96 & $\mathbf{2 . 1 9}$ & 1.34 & 1.22 \\
Insurance/ Private & $\mathbf{2 . 0 1}$ & $\mathbf{1 . 8 4}$ & $\mathbf{1 . 9 5}$ & $\mathbf{2 . 5 8}$ & 2.53 & $\mathbf{1 . 9 8}$ \\
pensions & $\mathbf{5 . 5 2}$ & $\mathbf{5 . 1 0}$ & $\mathbf{8 . 7 8}$ & 10.00 & 1.10 & 7.52 \\
Business assets & 1.39 & 1.43 & 2.04 & 1.38 & 0.85 & 1.35 \\
Tangible assets & 1.35 & 1.23 & 1.43 & 1.86 & 0.45 & 1.43 \\
Debt & $\mathbf{1 . 4 5}$ & $\mathbf{1 . 5 6}$ & $\mathbf{1 . 7 4}$ & $\mathbf{1 . 8 8}$ & 1.18 & 1.40 \\
\hline Total & & & & & & \\
\hline
\end{tabular}

Shaded cells indicate significant deviation $(\mathrm{p}<=0,05)$.

Note: Calculations are based on multiply imputed data

Source: SOEP 2002. 
Table 5: Comparison of chosen OLS regressions of net worth for women and men

\begin{tabular}{l|rrr|rrr}
\hline & Tomen & & & \multicolumn{1}{|c}{ Men } & & \\
\hline Variables & coeff. & sig. & std.err. & coeff. & sig. & std.err. \\
\hline Length of marriage & 242 & & 130 & 132 & & 158 \\
Number of marriages & -8116 & $*$ & 3290 & -17711 & $* *$ & 4067 \\
Immigrant & -44615 & $* *$ & 3831 & -38257 & $* *$ & 4766 \\
Have a partner & -29457 & $* *$ & 5037 & -10600 & & 6321 \\
Lived in East Germany before 1989 & -49818 & $* *$ & 3397 & -41759 & $* *$ & 4225 \\
Have kids under 5 years old & -5428 & & 4334 & -3158 & & 5348 \\
Lower vocational education & 915 & & 473 & 664 & & 471 \\
Upper vocational education & 23769 & $* *$ & 3248 & 15002 & $* *$ & 4699 \\
University degree & 36593 & $* *$ & 4647 & 36436 & $* *$ & 5908 \\
Being over 65 years old & 50401 & $* *$ & 4957 & 39855 & $* *$ & 5902 \\
Have high job autonomy & 19969 & $* *$ & 5294 & 18685 & $* *$ & 4663 \\
Permanent income & 34410 & $* *$ & 8462 & 200881 & $* *$ & 19285 \\
Years working full-time & 1430 & $* *$ & 174 & 2673 & $* *$ & 211 \\
\hline Years working part-time & 82006 & $* *$ & 13423 & 50224 & $*$ & 20482 \\
Years unemployed & 2333 & $* *$ & 230 & 1974 & $*$ & 820 \\
Not in the labor force & -275 & & 756 & 369 & & 995 \\
Labor market experience missing & 1443 & $* *$ & 189 & 2468 & $* *$ & 379 \\
Father with higher education & 33002 & $* *$ & 5943 & 6725 & & 7272 \\
Mother with higher education & -7842 & & 14967 & 3764 & & 20243 \\
Parent with higher education & -3929 & & 19461 & -3280 & & 25015 \\
Recent inheritance (after 1992) & 51231 & $* *$ & 4431 & 58125 & $* *$ & 5807 \\
"Old" inheritance (1949 till 1992) & 49182 & $* *$ & 5194 & 66878 & $* *$ & 5680 \\
Permanent income squared & -9223 & $* *$ & 1894 & -46318 & $* *$ & 3621 \\
Permanent income cube & 569 & $* *$ & 106 & 2630 & $* *$ & 177 \\
Constant & 21114 & $* *$ & 7859 & -30432 & & 24063 \\
\hline Observations & 7803 & & & 7803 & & \\
Adjusted R-squared & 0.18 & & & 0.27 & & \\
\hline \hline
\end{tabular}

Note: ${ }^{*}$ denotes statistical significance at the $1 \%$ level; ${ }^{* *}$ at the $5 \%$ level; shaded rows indicate the gender-specific coefficients are significantly different at the $5 \%$ level.

Source: SOEP 2002. 
Table 6: Two-fold Wealth decomposition results (Blinder-Oaxaca)

\begin{tabular}{|c|c|c|c|c|c|c|}
\hline \multicolumn{7}{|c|}{ Two-fold decomposition } \\
\hline $\begin{array}{l}\text { Women } \\
\text { reference } \\
\text { group }\end{array}$ & $\begin{array}{l}\text { Wealth } \\
\text { gap }\end{array}$ & $\begin{array}{l}\text { Average } \\
\text { wealth } \\
\text { Women }\end{array}$ & $\begin{array}{l}\text { Amount of gap due to } \\
\text { differences in } \\
\text { characteristics }\end{array}$ & $\begin{array}{l}\text { Women's av. } \\
\text { wealth if male } \\
\text { characteristics }\end{array}$ & $\begin{array}{l}\text { Amount of gap explained } \\
\text { with differences in } \\
\text { coefficients + unexplained } \\
\text { portion }\end{array}$ & $\begin{array}{l}\text { Average } \\
\text { wealth } \\
\text { Men }\end{array}$ \\
\hline & \multirow{3}{*}{$28199 *$} & 79562 & & 98400 & & 107761 \\
\hline & & & 18838 * & \multirow{2}{*}{\multicolumn{3}{|c|}{$\begin{array}{c}9362 \text { * } \\
33 \% \\
\end{array}$}} \\
\hline & & & $67 \%$ & & & \\
\hline \multicolumn{7}{|c|}{ Note: Women are the reference group. } \\
\hline \multirow[t]{4}{*}{$\begin{array}{l}\text { Men } \\
\text { reference } \\
\text { group }\end{array}$} & $\begin{array}{l}\text { Wealth } \\
\text { gap }\end{array}$ & $\begin{array}{l}\text { Average } \\
\text { wealth } \\
\text { Women }\end{array}$ & $\begin{array}{c}\text { Amount of gap explained } \\
\text { with differences in } \\
\text { characteristics }+ \\
\text { unexplained portion }\end{array}$ & $\begin{array}{c}\text { Men's av. } \\
\text { wealth if } \\
\text { women's wealth } \\
\text { function }\end{array}$ & $\begin{array}{l}\text { Amount of gap explained } \\
\text { with differences in } \\
\text { coefficients }(1)\end{array}$ & $\begin{array}{l}\text { Average } \\
\text { wealth } \\
\text { Men }\end{array}$ \\
\hline & \multirow{3}{*}{28199 * } & 79562 & & 125200 & & 107761 \\
\hline & & & 45638 * & & -17439 * & \\
\hline & & & $162 \%$ & & $-62 \%$ & \\
\hline
\end{tabular}

Note: Men are the reference group.

Note ${ }^{*}$ denotes statistical significance at the $1 \%$ level; ${ }^{* *}$ at the $5 \%$ level; and ${ }^{* * *}$ at the $10 \%$ level

(1). Differences arising from different conditional mean functions.

Source: SOEP 2002. 
Table 7: Three-fold Wealth decomposition results (Blinder-Oaxaca)

\begin{tabular}{|c|c|c|c|c|c|c|c|c|c|}
\hline \multicolumn{10}{|c|}{ Three-fold decomposition } \\
\hline & Wealth gap & $\begin{array}{l}\text { Average } \\
\text { wealth }\end{array}$ & $\begin{array}{l}\text { Amount of gap due } \\
\text { to differences in } \\
\text { characteristics }\end{array}$ & $\begin{array}{l}\text { Women's av. } \\
\text { wealth if male } \\
\text { characteristics }\end{array}$ & $\begin{array}{l}\text { Amount of gap } \\
\text { explained with } \\
\text { differences in } \\
\text { coefficients }\end{array}$ & $\begin{array}{l}\text { Women's av. } \\
\text { wealth if male's } \\
\text { characteristics } \\
\text { and wealth } \\
\text { function }\end{array}$ & Interaction & $\begin{array}{c}\text { Average } \\
\text { wealth }\end{array}$ & \\
\hline \multirow[t]{3}{*}{ Women } & & 79562 & & 98400 & & 80961 & & 107761 & Men \\
\hline & 28199 * & & 18838 * & & $-17439 *$ & & 26801 * & & \\
\hline & & & $67 \%$ & & $-62 \%$ & & $95 \%$ & & \\
\hline
\end{tabular}

Note: Men are the reference group.

Source: SOEP 2002. 
Table 8: Three-fold Wealth decomposition results (Juhn-Murphy-Pierce)

\begin{tabular}{|c|c|c|c|c|c|c|c|c|c|}
\hline \multicolumn{10}{|c|}{ Three-fold decomposition } \\
\hline & $\begin{array}{l}\text { Wealth } \\
\text { gap }\end{array}$ & $\begin{array}{l}\text { Average } \\
\text { wealth }\end{array}$ & $\begin{array}{l}\text { Amount of gap } \\
\text { explained with } \\
\text { differences in } \\
\text { characteristics }\end{array}$ & $\begin{array}{l}\text { Women's av. wealth if } \\
\text { men's characteristics }\end{array}$ & $\begin{array}{c}\text { Amount of gap } \\
\text { explained with } \\
\text { differences in } \\
\text { coefficients }\end{array}$ & $\begin{array}{l}\text { Women's av. } \\
\text { wealth if } \\
\text { male's } \\
\text { characteristic } \\
\mathrm{s} \text { and wealth } \\
\text { function }\end{array}$ & $\begin{array}{l}\text { Un- } \\
\text { explained }\end{array}$ & $\begin{array}{l}\text { Average } \\
\text { wealth }\end{array}$ & \\
\hline Women & & 79562 & & 125034 & & 107595 & & 107761 & Men \\
\hline \multirow[t]{2}{*}{ JMP } & 28199 & & 45472 & & -17439 & & 166 & & \\
\hline & & & $161 \%$ & & $-62 \%$ & & $0 \%$ & & \\
\hline Women & & 79562 & & 98400 & & 80961 & & 107761 & Men \\
\hline \multirow[t]{2}{*}{ Oaxaca } & 28199 * & & 18838 * & & $-17439 *$ & & $26801 *$ & & \\
\hline & & & $67 \%$ & & $-62 \%$ & & $95 \%$ & & \\
\hline
\end{tabular}

Note: Male group coefficients as the reference group.

Source: SOEP 2002. 
Table 9: Wealth decomposition results across the wealth distribution (Juhn-Murphy-Pierce).

\begin{tabular}{|c|c|c|c|c|}
\hline & $\begin{array}{l}\text { Wealth } \\
\text { gap }\end{array}$ & $\begin{array}{l}\text { Amount of gap } \\
\text { explained with } \\
\text { differences in } \\
\text { characteristics }\end{array}$ & $\begin{array}{l}\text { Amount of gap } \\
\text { explained with } \\
\text { differences in } \\
\text { coefficients }\end{array}$ & Unexplained \\
\hline 10th & 0 & 49780 & -32249 & -17531 \\
\hline 25th & $\begin{array}{r}3950 \\
100\end{array}$ & $\begin{array}{r}31266 \\
792\end{array}$ & $\begin{array}{r}-19683 \\
-498\end{array}$ & $\begin{array}{r}-7633 \\
-193\end{array}$ \\
\hline 50th & $\begin{array}{r}18250 \\
100\end{array}$ & $\begin{array}{r}36254 \\
199\end{array}$ & $\begin{array}{r}-9596 \\
-53\end{array}$ & $\begin{array}{r}-8408 \\
-46\end{array}$ \\
\hline 75th & $\begin{array}{r}32500 \\
100\end{array}$ & $\begin{array}{r}46525 \\
143\end{array}$ & $\begin{array}{r}-16480 \\
-51\end{array}$ & $\begin{array}{r}2455 \\
8\end{array}$ \\
\hline 90th & $\begin{array}{r}67959 \\
100\end{array}$ & $\begin{array}{r}62288 \\
92 \\
\end{array}$ & $\begin{array}{r}-13837 \\
-20 \\
\end{array}$ & $\begin{array}{r}19508 \\
29 \\
\end{array}$ \\
\hline P90-P10 & $\begin{array}{r}67959 \\
100\end{array}$ & $\begin{array}{r}12508 \\
18\end{array}$ & $\begin{array}{r}18412 \\
27\end{array}$ & $\begin{array}{r}37039 \\
55\end{array}$ \\
\hline P90-P50 & $\begin{array}{r}49709 \\
100\end{array}$ & $\begin{array}{r}26034 \\
52\end{array}$ & $\begin{array}{r}-4241 \\
-9\end{array}$ & $\begin{array}{r}27916 \\
56\end{array}$ \\
\hline P50-P10 & $\begin{array}{r}18250 \\
100\end{array}$ & $\begin{array}{r}-13526 \\
-74\end{array}$ & $\begin{array}{r}22653 \\
124\end{array}$ & $\begin{array}{r}9123 \\
50\end{array}$ \\
\hline P75-P25 & $\begin{array}{r}28550 \\
100\end{array}$ & $\begin{array}{r}15259 \\
53\end{array}$ & $\begin{array}{r}3203 \\
11\end{array}$ & $\begin{array}{r}10088 \\
35\end{array}$ \\
\hline
\end{tabular}

Note: Men as the reference group; values in parenthesis give the share of the wealth gap which can be attributed to differences in characteristics, differences in coefficients, and the unexplained part, respectively.

Source: SOEP 2002. 
Table 10: Wealth decomposition results across the wealth distribution (DiNardo, Fortin, Lemieux).

\begin{tabular}{|c|c|c|c|c|c|c|}
\hline & $\begin{array}{l}\text { Wealth } \\
\text { gap }\end{array}$ & $\begin{array}{c}\text { Income and } \\
\text { Labor market } \\
\text { experience }\end{array}$ & $\begin{array}{l}\text { Education } \\
\text { Level }\end{array}$ & $\begin{array}{c}\text { Inter- } \\
\text { generational } \\
\text { Factors }\end{array}$ & $\begin{array}{l}\text { Demographic } \\
\text { Characteristics }\end{array}$ & $\begin{array}{c}\text { Un- } \\
\text { explained }\end{array}$ \\
\hline 10th & 0 & 0 & 0 & 0 & 0 & 0 \\
\hline se & 0 & 6229 & 5673 & 578 & 601 & 12501 \\
\hline 25th & 3950 & 3946 & 904 & 154 & -54 & -1000 \\
\hline se & 934 & 1060 & 706 & 46 & 978 & 1129 \\
\hline$\%$ & 100 & 100 & 23 & 4 & -1 & -25 \\
\hline 50th & 18250 & 34002 & 3721 & 560 & -533 & -19500 \\
\hline se & 2558 & 39329 & 5268 & 4536 & 5331 & 51502 \\
\hline$\%$ & 100 & 186 & 20 & 3 & -3 & -107 \\
\hline 75th & 32500 & 1629 & -11660 & -4951 & -17339 & 64821 \\
\hline se & 3663 & 64119 & 7279 & 1400 & 1977 & 65798 \\
\hline$\%$ & 100 & 5 & -36 & -15 & -53 & 199 \\
\hline 90th & 67959 & 85226 & 7862 & 1950 & 140 & -27220 \\
\hline se & 7682 & 62465 & 26109 & 888 & 9598 & 70097 \\
\hline$\%$ & 100 & 125 & 12 & 3 & 0 & -40 \\
\hline P50-P10 & 18250 & 34002 & 3721 & 560 & -533 & -19500 \\
\hline se & 2558 & 37901 & 6575 & 4468 & 5304 & 49666 \\
\hline$\%$ & 100 & 186 & 20 & 3 & -3 & -107 \\
\hline P75-P25 & 28550 & -2317 & -12564 & -5105 & -17285 & 65821 \\
\hline $\mathrm{Se}$ & 3268 & 63646 & 7429 & 1418 & 2292 & 65249 \\
\hline$\%$ & 100 & -8 & -44 & -18 & -61 & 231 \\
\hline P90-P50 & 49709 & 51225 & 4141 & 1390 & 673 & -7720 \\
\hline se & 6264 & 54551 & 25231 & 4599 & 10490 & 69153 \\
\hline$\%$ & 100 & 103 & 8 & 3 & 1 & -16 \\
\hline
\end{tabular}

Note: values in parentheses give the share of the wealth gap attributable to the various factors.

Source: SOEP 2002. 


\section{Appendix}

\section{Appendix A: The decomposition methods}

All decomposition analyses in this paper were performed using Stata@ (version 9.2). The procedures used are "OAXACA.DO", "JMPIERCE.DO" (by Ben Jann) and "DECOMPOSE2.DO" generously provided by Vincent Hildebrand for the DFL decomposition.

\section{Appendix A.1: The Oaxaca-Blinder decomposition}

The general specification for the Oaxaca decomposition is the following:

$$
\begin{aligned}
& \Delta \mu^{(M, W)}=\left[\mu\left(X^{M}\right)-\mu\left(X^{W}\right)\right] \beta^{W}+\mu\left(X^{W}\right)\left[\beta^{M}-\beta^{W}\right]+\left[\mu\left(X^{M}\right)-\mu\left(X^{W}\right)\right]\left[\beta^{M}-\beta^{W}\right] \\
& \Delta \mu^{(M, W)}=I+I I+I I I
\end{aligned}
$$

$\mu(\bullet)^{j}$ is the conditional mean function for $\mathrm{j}=\mathrm{W}$ oman, Man and $\beta^{j}$-coefficients for $\mathrm{j}$-group and $X^{j}$ characteristics of $\mathrm{j}$ group. In this three-fold decomposition, the first component expresses the composition effect in the gap that comes from the differences in the mean outcome based on characteristics $\mathrm{X}$ between group $M$ and $W$, the second is the effect due to differences in coefficients (this is the estimated effects) between these two groups, and the third term is the interaction term of the two effects. It must be kept in mind that the estimated coefficient effect commonly known as "discrimination" will be incorrect if there are characteristics that affect the explanatory variable (in this case wealth), but have been omitted from the regression ${ }^{9}$ - the so-called omitted variable problem. Others who believe that there is prevalent discrimination and that the magnitude of discrimination is greater than the coefficient effect itself argue that even differences in qualifications and credentials may be the result of pre-market discrimination - the so-called included variable problem.

Depending on which group (either $M$ or $W$ ) we consider as the reference group, we can specify alternative two-fold decompositions:

If we assume $M$ to be the reference group (or the non-discriminatory group) or the group whose coefficient structure prevails (in our case, the wealth function), the "explained" part of the differential will be the sum of components I and III and the "unexplained" portion will be equal to component II.

$$
\Delta \mu^{(M, W)}=\left[\mu\left(X^{M}\right)-\mu\left(X^{W}\right)\right] \beta^{M}+\mu\left(X^{W}\right)\left[\beta^{M}-\beta^{W}\right]
$$

An alternative decomposition of the group differential would be to specify $W$ to be the reference, non-discriminatory group. Assuming that the coefficient structure from group $W$ prevails, the "explained" part of the differential will be equal to component I and the "unexplained" component will be the sum of II and III.

$$
\Delta \mu^{(M, W)}=\left[\mu\left(X^{M}\right)-\mu\left(X^{W}\right)\right] \beta^{W}+\mu\left(X^{M}\right)\left[\beta^{M}-\beta^{W}\right]
$$

\footnotetext{
${ }^{9}$ In this case the degree of discrimination would be over-estimated as the coefficients are the sum of discrimination and differences in unobserved skills.
} 


\section{Appendix A.2: The Juhn-Murphy-Pierce decomposition}

Following closely on Juhn, Murphy, and Pierce (1993) the framework is the following:

First, a simple model is specified for the two groups

$$
Y_{j}=X_{j} \beta_{j}+U_{j}
$$

where $Y_{j}$ are the vectors of the values of the dependent variable in two samples, $X_{j}$ are the data matrices (observable quantities), $\beta_{j}$ are the vectors of estimated coefficients (observable prices) and $U_{j}$ are the residuals (unobservables, i.e., unmeasured prices and quantities). $j=M, W$ (men and women, respectively).

Let $F_{j}$ (.) denote the cumulative distribution functions of the residuals for group $j=M, W$. Then the residual gap is thought to consist of two components: an individual's percentile in the residual distribution $p_{i}$, and the distribution function of the wealth equation residuals $F_{j}($.$) .$ For example, take

$$
p_{i j}=F_{j}\left(u_{i j} \mid x_{i j}\right)
$$

to be the percentile of an individual residual in the residual distribution of model $i$.

By definition we can write

$$
u_{i j}=F_{i}^{-1}\left(p_{i j} \mid x_{i j}\right) \text {, where } F_{j}^{-1}(.) \text { is the inverse of the cumulative distribution function }
$$
for group $j$.

Next, let us assume $F($.$) to be the reference residual distribution (e.g., the average residual$ distribution over both samples) and $\bar{\beta}$ an estimate of benchmark coefficients (e.g., the coefficients from a pooled model over the whole sample).

Using this framework, we can reconstruct hypothetical outcome distributions with any of the components held fixed. We can then determine

1. hypothetical outcomes with varying quantities between the groups and fixed prices (coefficients) and a fixed residual distribution as

$$
y_{i j}^{(1)}=x_{i j} \bar{\beta}+F^{-1}\left(p_{i j} \mid x_{i j}\right)
$$

2. hypothetical outcomes with varying quantities and varying prices and fixed residual distribution as

$$
y_{i j}^{(2)}=x_{i j} \beta_{j}+F^{-1}\left(p_{i j} \mid x_{i j}\right)
$$

3. outcomes with varying quantities, varying prices and a varying residual distribution as

$$
y_{i j}^{(3)}=x_{i j} \beta_{j}+F_{j}^{-1}\left(p_{i j} \mid x_{i j}\right)
$$

These last outcomes are actually equal to the originally observed values, i.e.: 


$$
y_{i j}^{(3)}=y_{i j}=x_{i j} \beta_{j}+u_{i j}
$$

Let a capital letter stand for a summary statistic of the distribution of the variable denoted by the corresponding lower-case letter. For instance, $\mathrm{Y}$ may be the mean or the interquartile range of the distribution of $\mathrm{y}$. The differential $Y_{M}-Y_{W}$ can then be decomposed as

$$
\begin{gathered}
Y_{M}-Y_{W}=\left[Y_{M}^{(1)}-Y_{W}^{(1)}\right]+\left[\left(Y_{M}^{(2)}-Y_{W}^{(2)}\right)-\left(Y_{M}^{(1)}-Y_{W}^{(1)}\right)\right]+\left[\left(Y_{M}^{(3)}-Y_{W}^{(3)}\right)-\left(Y_{M}^{(2)}-Y_{W}^{(2)}\right)\right]= \\
=T=Q+P+U
\end{gathered}
$$

Where $T$ is the total difference; $Q$ can be attributed to differences in observable quantities; $P$ to differences in observable prices, and $U$ to differences in unobservable quantities and prices. This last component not only captures the effect of unmeasured prices, and the effect of the differences in the distribution of unmeasured characteristics (e.g., one of the unmeasured characteristics is more important for men or women for generating wealth), but also measurement error (e.g., men and women report wealth differently).

The major advantage of the Juhn-Murphy-Pierce framework is that it allows us to look at how differences in characteristics affect the entire wealth distribution and not just the variance. We can identify how differences in the distribution affect other inequality measures or how the effects on inequality are different below and above the mean.

\section{Appendix A.3: The DiNardo-Fortin-Lemieux (DFL) decomposition}

In their decomposition, DiNardo, Fortin, and Lemieux use a semiparametric decomposition approach and avoid making parametric assumptions about the conditional mean function. Instead they use reweighting techniques and consider comparisons of probability density functions such as in the case of differences in wealth between men and women:

$\Delta g^{(M, W)}=g^{M}(w)-g^{W}(w)$, where $g^{j}($.$) is the marginal distribution of wealth w$ for group $j$; for an observation with characteristics $x$ and it can be expressed via $g(w)=\int f(w \mid x) h(x) d x$. The conditional distribution $f(. \mid$.$) can be thought of as being$ analogous to an estimated regression line and the marginal density of $x, h($.$) to the vector of$ characteristics.

Next, we can specify each density separately by gender:

$g^{j}(w)=g(w \mid j=i)=\int f^{j}(w \mid x) h(x \mid j=i) d x$, where $j=M, F($ men,women $)$.

With this we can specify various counterfactual densities.

For example,

What would be the wealth distribution of women if they had the characteristics of men

$g_{C F}^{W}(w)=g(w \mid j=F)=\int f^{W}(w \mid x) h(x \mid j=M) d x=\int f^{W}(w \mid x) h(x \mid j=F) \Psi(x) d x$

The innovation here is the reweighting function $\Psi($.$) , which is defined in the following way:$

$\Psi^{(M, W)}(x)=\frac{h(x \mid j=F)}{h(x \mid j=M)}$ since $h(x \mid j=i)=\frac{P(j=i \mid x)}{P(j=i)}$ then using Bayes' Rule: 
$\Psi^{(M, W)}(x)=\frac{P(j=F \mid x) P(j=M)}{P(j=M \mid x) P(j=F)}$,

where unlike $h(x \mid j=i)$ each of the components can easily be estimated (e.g., surveyweighted logits) and $P(j=i \mid x)$ is the probability that a randomly selected individual with characteristics $x$ belongs to group $i$ if individuals from both groups are pooled in a common population and $P(j=i)$ is the probability that a randomly selected individual belongs to group $j$ in a pooled population. $g^{j}(w)$ can be estimated using Kernel density estimators.

In this case the decomposition would be the following:

$\Delta g^{(M, W)}=g^{M}(w)-g^{W}(w)=\left(g^{M}-g_{C F}^{F}\right)+\left(g_{C F}^{F}-g^{F}\right)$

The second component would express differences due to characteristics and the first would capture the unobservables.

Another question we could ask is:

1. What would the wealth distribution of men be if they had the characteristics of women $g_{C F}^{M}(w)=g(w \mid j=M)=\int f^{M}(w \mid x) h(x \mid j=F) d x=\int f^{M}(w \mid x) h(x \mid j=M) \Psi^{-1}(x) d x$

The decomposition would then be the following:

$\Delta g^{(M, W)}=g^{M}(w)-g^{W}(w)=\left(g^{M}-g_{C F}^{M}\right)+\left(g_{C F}^{M}-g^{F}\right)$ with the first component capturing the differences due to characteristics and the second due to unobservables.

In our case, we partition the vector of characteristics into four groups $x=\{l, e, i, d\}$ and we reweight the wealth distribution of men (Barsky et al 2002):

1. Labor market experience $(l)$ (self-employed ${ }^{10}$, not in the labor force, being over 65 years of age, lifetime experience working full-time, lifetime experience working parttime, lifetime experience being unemployed, missing information on lifetime labor market experience, have high job autonomy, permanent income)

2. Educational level (e) (no or basic, lower vocational, upper vocational, university)

3. Intergenerational characteristics $(i)$ (father with higher education, mother with higher education, parent with higher education, received a recent inheritance (since 1992), received an inheritance in the past (1949 to 1992))

4. Demographic characteristics $(d)$ (have a partner, length of marriage, number of marriages, immigrant or German national coming from abroad, lived in East Germany before 1989, have children under the age of five)

Our decomposition can then be written in the following way

$$
\begin{aligned}
& g^{j}(w)=g(w \mid j)=\int_{l} \int_{e} \int_{i} \int_{d} f^{j}(w, l, e, i, d \mid j=i) \text { dldedidd }= \\
& =\int_{l} \int_{e} \int_{i} \int_{d} f^{j}(w \mid l, e, i, d, j=i) f_{x}(l, e, i, d \mid g=i) \text { dldedidd }= \\
& =\int_{l}^{l} \int_{e} \int_{i} \int_{d} f^{j}(w \mid l, e, i, d, j=i) h_{l \mid e i d}(l \mid e, i, d, j=i) h_{e \mid i d}(e \mid i, d, j) h_{i \mid d}(i \mid d, j) h_{d}(d \mid j) \text { dldedidd }
\end{aligned}
$$

\footnotetext{
${ }^{10} \mathrm{We}$ exclude the self-employed from the final sample.
} 
Next, we follow the methodology of Cobb-Clark and Hildebrand (2006) and Gibson et al (2007) and create several counterfactuals:

1. What would the wealth distribution of males be if they had women's labor market experience

$g_{C F}^{1}=$

$=\int_{l} \int_{e} \int_{i} \int_{d} f^{M}(w \mid l, e, i, d, j=M) h_{l \mid e i d}(l \mid e, i, d, j=F) h_{e \mid j d}(e \mid i, d, j=M) h_{i \mid d}(i \mid d, j=M) h_{d}(d \mid j=M) d l d e d i d d$

2. What would the wealth distribution of males be if they had women's labor market experience, and education

$g_{C F}^{2}=$

$=\int_{l} \int_{e} \int_{i} \int_{d} f^{M}(w \mid l, e, i, d, j=M) h_{l \mid e i d}(l \mid e, i, d, j=F) h_{e \mid j d}(e \mid i, d, j=F) h_{i \mid d}(i \mid d, j=M) h_{d}(d \mid j=M) d l d e d i d d$

3. What would the wealth distribution of males be if they had women's labor market experience, education, and intergenerational characteristics

$g_{C F}^{3}=$

$=\int_{l} \int_{e} \int_{i} \int_{d} f^{M}(w \mid l, e, i, d, j=M) h_{l \mid e i d}(l \mid e, i, d, j=F) h_{e \mid i d}(e \mid i, d, j=F) h_{i \mid d}(i \mid d, j=F) h_{d}(d \mid j=M) d l d e d i d d$

4. What would the wealth distribution of males be if they had women's labor market experience, education, intergenerational, and demographic characteristics

$g_{C F}^{4}=$

$=\int_{l} \int_{e} \int_{i} \int_{d} f^{M}(w \mid l, e, i, d, j=M) h_{l \mid e i d}(l \mid e, i, d, j=F) h_{e \mid i d}(e \mid i, d, j=F) h_{i \mid d}(i \mid d, j=F) h_{d}(d \mid j=F)$ dldedidd

With these we obtain our decomposition and we the appropriate reweighting techniques can estimate:

$$
\begin{aligned}
& \Delta g^{(M, W)}=g^{M}(w)-g^{W}(w)= \\
& =\left[g^{M}(w)-g_{C F}{ }^{1}(w)\right]+\left[g_{C F}{ }^{1}(w)-g_{C F}{ }^{2}(w)\right]+\left[g_{C F}{ }^{2}(w)-g_{C F}{ }^{3}(w)\right]+ \\
& +\left[g_{C F}{ }^{3}(w)-g_{C F}{ }^{4}(w)\right]+\left[g_{C F}{ }^{4}(w)-g^{W}(w)\right]
\end{aligned}
$$

Since the ordering of these factor decompositions matters, we use all possible orderings and the presented results are averages across all orderings. 
Appendix Table B.1: Variable definitions

\begin{tabular}{ll} 
Variables & \\
\hline Imarriage & Length of marriage \\
nrmarriages & Number of marriages \\
migback & Immigrant \\
partner & Have a partner \\
loc89east & Lived in East Germany before 1989 \\
kids04 & Have kids under 5 years old \\
ledu_2 & Lower vocational education \\
ledu_3 & Upper vocational education \\
ledu_4 & University degree \\
over65 & Being over 65 years old \\
autonom & Have high job autonomy \\
perminc & Permanent income \\
expft02 & Years working full-time \\
exppt02 & Years working part-time \\
expue02 & Years unemployed \\
notlabor & Not in the labor force \\
expmiss & Labor market experience missing \\
hiedu_f & Father with higher education \\
hiedu_m & Mother with higher education \\
hiedu_p & Parent with higher education \\
inheri1 & Recent inheritance (after 1992) \\
inheri2 & "Old" inheritance (1949 till 1992) \\
\hline
\end{tabular}


Appendix Table B.2a: OLS regressions of net worth for men (standard errors in parentheses).

\begin{tabular}{|c|c|c|c|c|c|c|c|c|}
\hline & (1) & (2) & (3) & (4) & (5) & (6) & (7) & (8) \\
\hline \multirow[t]{2}{*}{ Imarriage } & 1179.37 & 1361.23 & 123.39 & 125.52 & 63.57 & 130.31 & 135.1 & 131.63 \\
\hline & $(130.15)^{\star *}$ & $(132.37)^{\star \star}$ & (163.53) & (161.38) & (163.51) & $(160.11)$ & (157.74) & (157.80) \\
\hline \multirow[t]{2}{*}{ nrmarriages } & & 3473.67 & -17710.4 & -17586.38 & -14400.45 & -17655.15 & -17430.38 & -17710.83 \\
\hline & & (3891.37) & $(4215.07)^{\star \star}$ & $(4159.08)^{\star \star}$ & $(4209.56)^{\star \star}$ & $(4128.72)^{\star \star}$ & $(4066.82)^{\star \star}$ & $(4067.25)^{\star \star}$ \\
\hline \multirow[t]{2}{*}{ migback } & -68324.5 & -51741.5 & -44266.6 & -36745.25 & -41889.8 & -46481.29 & -38574.23 & -38257.07 \\
\hline & $(4943.90)^{\star *}$ & $(4903.50)^{\star \star}$ & $(4907.51)^{\star \star}$ & $(4872.40)^{\star \star}$ & $(4925.41)^{\star *}$ & $(4809.10)^{\star \star}$ & $(4765.20)^{\star *}$ & $(4765.81)^{\star *}$ \\
\hline \multirow[t]{2}{*}{ partner } & -27173.7 & -8241.14 & -12079.9 & -12693.95 & -20751.19 & -10644.83 & -11206.73 & -10600.33 \\
\hline & $(5914.27)^{\star *}$ & (6593.09) & (6540.52) & $(6462.07)^{*}$ & $(6525.59)^{\star *}$ & (6410.45) & $(6322.40)$ & $(6321.21)$ \\
\hline \multirow[t]{2}{*}{ loc89east } & -81562.2 & -57449 & -52618.6 & -49582.42 & -65194.88 & -46686.09 & -43187.44 & -41758.72 \\
\hline & $(4269.64)^{\star \star}$ & $(4341.99)^{\star \star}$ & $(4329.69)^{\star \star}$ & $(4290.85)^{\star \star}$ & $(4211.62)^{\star \star}$ & $(4301.91)^{\star \star}$ & $(4255.55)^{\star \star}$ & $(4225.46)^{\star \star}$ \\
\hline \multirow[t]{2}{*}{ kids04 } & -27857.7 & -28780.9 & -4742.87 & -6028.88 & -5921.41 & -1734.75 & -3176.98 & -3158.3 \\
\hline & $(5421.13)^{\star *}$ & $(5322.93)^{\star \star}$ & (5538.25) & $(5467.71)$ & (5541.71) & (5424.93) & (5346.17) & $(5348.41)$ \\
\hline \multirow{2}{*}{ over65 } & 144.01 & 1552.51 & 44.92 & 248.09 & -673.47 & 359.45 & 589.23 & 664.3 \\
\hline & $(470.59)$ & $(469.17)^{\star \star}$ & (486.55) & $(480.96)$ & (483.25) & (477.98) & (471.67) & (471.07) \\
\hline \multirow[t]{2}{*}{ _ledu_2 } & 18814.46 & 12725.81 & 19039.44 & 16973.13 & 17626.81 & 17272.27 & 14996.91 & 15002.04 \\
\hline & $(4977.28)^{\star \star}$ & $(4873.71)^{\star \star}$ & $(4866.60)^{\star \star}$ & $(4804.73)^{\star \star}$ & $(4869.55)^{\star \star}$ & $(4765.83)^{\star \star}$ & $(4697.22)^{\star \star}$ & $(4699.20)^{\star \star}$ \\
\hline \multirow[t]{2}{*}{ ledu_3 } & 42090.5 & 34302.14 & 45000.28 & 39213.45 & 40031.95 & 42565.28 & 36903.68 & 36436.1 \\
\hline & $(6233.45)^{\star *}$ & $(6099.52)^{\star \star}$ & $(6100.77)^{\star \star}$ & $(6041.37)^{\star \star}$ & $(6122.87)^{\star *}$ & $(5977.66)^{\star \star}$ & $(5908.88)^{\star *}$ & $(5908.92)^{\star *}$ \\
\hline \multirow[t]{2}{*}{ _ledu_4 } & 68295.77 & 47476.84 & 60861.58 & 52226.93 & 61863.17 & 48150.37 & 40145.02 & 39854.65 \\
\hline & $(6016.62)^{\star *}$ & $(5971.40)^{\star *}$ & $(5999.50)^{\star *}$ & $(5998.50)^{\star \star}$ & $(6042.75)^{\star *}$ & $(5917.75)^{\star *}$ & $(5900.51)^{\star *}$ & $(5902.05)^{* *}$ \\
\hline \multirow[t]{2}{*}{ autonom } & 59211.07 & 27685.92 & 33932.91 & 35139.34 & 50487.69 & 17992.15 & 19047.11 & 18684.8 \\
\hline & $(4599.06)^{\star *}$ & $(4774.27)^{\star \star}$ & $(4741.80)^{\star \star}$ & $(4683.67)^{\star \star}$ & $(4625.87)^{\star *}$ & $(4730.58)^{\star \star}$ & $(4663.19)^{\star *}$ & $(4663.29)^{\star *}$ \\
\hline \multirow[t]{2}{*}{ perminc } & & 58213.75 & 58665.44 & 57705.88 & 21630.21 & 503796.7 & 575168.4 & 200881 \\
\hline & & $(2939.99)^{\star \star}$ & $(3115.87)^{\star *}$ & $(3080.49)^{\star *}$ & $(1863.39)^{\star *}$ & $(139394.70)^{\star *}$ & $(137525.20)^{\star *}$ & $(19285.88)^{\star *}$ \\
\hline \multirow[t]{2}{*}{ zeroinc } & & 564944.3 & 567262.9 & 551733.7 & & 982839.3 & 1168524 & \\
\hline & & $(37337.42)^{\star \star}$ & $(38027.75)^{\star *}$ & $(37801.62)^{* *}$ & & $(431061.50)^{*}$ & $(425113.80)^{\star *}$ & \\
\hline \multirow[t]{2}{*}{ expft02 } & & & 2911.73 & 2705.58 & 2690.23 & 2892.37 & 2643.43 & 2672.84 \\
\hline & & & $(217.16)^{\star \star}$ & $(215.75)^{\star \star}$ & $(218.67)^{\star \star}$ & $(212.85)^{\star \star}$ & $(211.16)^{\star \star}$ & $(210.98)^{\star \star}$ \\
\hline \multirow[t]{2}{*}{ expmiss } & & & 67989.16 & 75942.2 & 102466.1 & 44419.84 & 50474.27 & 50224 \\
\hline & & & $(21154.82)^{\star *}$ & $(20899.92)^{\star *}$ & $(21102.57)^{\star \star}$ & $(20754.99)^{*}$ & $(20473.55)^{\star}$ & $(20481.97)^{*}$ \\
\hline \multirow{2}{*}{ exppt02 } & & & 2604.42 & 2152.9 & 1045.08 & 2352.84 & 1901.47 & 1974.2 \\
\hline & & & $(848.55)^{\star *}$ & $(838.37)^{\star}$ & (846.22) & $(831.56)^{\star \star}$ & $(820.14)^{*}$ & $(820.06)^{*}$ \\
\hline \multirow[t]{2}{*}{ expue02 } & & & 1493.02 & 1692.9 & -1254.84 & -13.5 & 71.55 & 369.49 \\
\hline & & & (1025.86) & (1012.65) & (1005.74) & (1015.22) & (1000.58) & (995.12) \\
\hline notlabor & & & 2647.52 & 2618.76 & 2002.12 & 2447.93 & 2392.21 & 2468.02 \\
\hline & & & $(392.20)^{* *}$ & $(387.06)^{\star *}$ & $(389.95)^{\star *}$ & $(385.39)^{\star \star}$ & $(379.71)^{\star *}$ & $(378.87)^{\star \star}$ \\
\hline hiedu_f & & & & 15472.44 & 28384.14 & & 6084.02 & 6725.46 \\
\hline & & & & $(7423.29)^{*}$ & $(7470.15)^{\star *}$ & & $(7273.00)$ & (7272.32) \\
\hline hiedu_m & & & & 1314.63 & 741.41 & & 3525.15 & 3764.24 \\
\hline & & & & (20702.19) & (20982.36) & & (20234.58) & (20242.92) \\
\hline hiedu_p & & & & 6187.48 & -5564 & & -3516.33 & -3280.07 \\
\hline & & & & (25577.56) & (25910.91) & & (25004.54) & (25014.93) \\
\hline inheri1 & & & & 54819.06 & 56873.11 & & 58446.4 & 58125.23 \\
\hline & & & & $(5936.16)^{\star *}$ & $(6014.81)^{\star *}$ & & $(5806.15)^{\star *}$ & $(5807.42)^{\star *}$ \\
\hline inheri2 & & & & 64082.74 & 63213.26 & & 67249.93 & 66877.95 \\
\hline & & & & $(5806.58)^{\star *}$ & $(5884.86)^{\star *}$ & & $(5678.91)^{\star \star}$ & $(5679.69)^{\star *}$ \\
\hline inc2 & & & & & & -77287.59 & -85772.65 & -46317.75 \\
\hline & & & & & & $(14995.86)^{\star \star}$ & $(14803.11)^{\star \star}$ & $(3620.75)^{\star \star}$ \\
\hline inc3 & & & & & & 3674.2 & 3996.8 & 2629.66 \\
\hline & & & & & & $(534.42)^{\star \star}$ & $(527.85)^{\star \star}$ & $(176.85)^{\star \star}$ \\
\hline Constant & 66559.88 & -524794 & -599975 & -593793.6 & -221312.4 & -1002938 & -1193379 & -30432.09 \\
\hline & $(5541.93)^{\star \star}$ & $(30471.44)^{\star *}$ & $(33712.90)^{\star *}$ & $(33295.98)^{\star \star}$ & $(21674.91)^{\star *}$ & $(429784.10)^{*}$ & $(423768.10)^{\star \star}$ & -24062.54 \\
\hline Observations & 7803 & 7803 & 7803 & 7803 & 7803 & 7803 & 7803 & 7803 \\
\hline Adjusted R- & 0.15 & 0.19 & 0.21 & 0.23 & 0.21 & 0.24 & 0.27 & 0.27 \\
\hline
\end{tabular}

Note: ${ }^{*}$ significant at $5 \%$ level; ${ }^{* *}$ significant at $1 \%$ level Source: SOEP 2002 
Appendix Table B.2b: OLS regressions of net worth for women (standard errors in parentheses)

\begin{tabular}{|c|c|c|c|c|c|c|c|c|}
\hline & (1) & (2) & (3) & (4) & (5) & (6) & (7) & (8) \\
\hline \multirow[t]{2}{*}{ lmarriage } & 1024.25 & 1036.74 & 261.14 & 241.67 & 239.62 & 249.22 & 230.35 & 241.53 \\
\hline & $(99.55)^{* *}$ & $(103.83)^{* *}$ & $(131.93)^{*}$ & -129.83 & -129.94 & -131.54 & -129.48 & -129.53 \\
\hline \multirow[t]{2}{*}{ nrmarriages } & & 3983.69 & -6766.83 & -7177.72 & -6440.38 & -7763.13 & -8109.06 & -8115.71 \\
\hline & & (3113.63) & $(3346.90)^{*}$ & $(3293.87)^{*}$ & (3290.76) & $(3339.72)^{*}$ & $(3287.66)^{*}$ & $(3289.92)^{*}$ \\
\hline \multirow[t]{2}{*}{ migback } & -57630.47 & -57942.24 & -50496.54 & -45171.9 & -45824.98 & -49307.4 & -44040.14 & -44615.19 \\
\hline & $(3845.73)^{* *}$ & $(3864.34)^{* *}$ & $(3877.40)^{* * *}$ & $(3838.96)^{* * *}$ & $(3838.23)^{* *}$ & $(3868.93)^{* * *}$ & $(3831.67)^{* * *}$ & $(3830.64)^{* *}$ \\
\hline \multirow[t]{2}{*}{ partner } & -29081.36 & -26273.55 & -27692.74 & -29562.35 & -27646.02 & -27268.57 & -29109.73 & -29456.88 \\
\hline & $(4498.28)^{* *}$ & $(5111.33)^{* *}$ & $(5124.95)^{* *}$ & $(5047.19)^{* * *}$ & $(5025.48)^{* *}$ & $(5110.16)^{* *}$ & $(5034.16)^{* *}$ & $(5036.61)^{* *}$ \\
\hline \multirow[t]{2}{*}{ loc89east } & -62168.82 & -60859 & -54471.22 & -52617.09 & -52865.19 & -50771.9 & -49123.29 & -49818.45 \\
\hline & $(3206.53)^{* *}$ & $(3255.32)^{* *}$ & $(3426.17)^{* *}$ & $(3375.03)^{* *}$ & $(3377.21)^{* *}$ & $(3451.87)^{* *}$ & $(3401.09)^{* *}$ & $(3397.38)^{* *}$ \\
\hline \multirow[t]{2}{*}{ kids04 } & -21457 & -18701.7 & -3956.72 & -8022.65 & -10160.25 & -1588.83 & -5759.57 & -5428.38 \\
\hline & $(4141.32)^{* *}$ & $(4212.53)^{* *}$ & $(4383.72)$ & (4320.97) & $(4286.81)^{*}$ & (4393.42) & (4332.11) & (4334.02) \\
\hline \multirow[t]{2}{*}{ over65 } & 1090.32 & 1425.17 & 455.46 & 664.99 & 434.36 & 687.65 & 878.86 & 915.26 \\
\hline & $(454.15)^{*}$ & $(461.28)^{* *}$ & (478.88) & (471.64) & $(468.00)$ & $(479.52)$ & $(472.36)$ & (472.57) \\
\hline \multirow[t]{2}{*}{ _Iedu_2 } & 23850.11 & 23699.66 & 27556.39 & 23571.45 & 24107.54 & 28213.92 & 24247.19 & 23768.68 \\
\hline & $(3276.58)^{* * *}$ & $(3291.28)^{* *}$ & $(3298.19)^{* *}$ & $(3254.76)^{* * *}$ & $(3254.35)^{* *}$ & $(3291.05)^{* * *}$ & $(3248.68)^{* *}$ & $(3247.92)^{* *}$ \\
\hline \multirow[t]{2}{*}{ _Iedu_3 } & 35586.91 & 35476.23 & 44632.35 & 37853.77 & 39204.02 & 43641.04 & 37037.49 & 36592.68 \\
\hline & $(4604.64)^{* *}$ & $(4654.36)^{* *}$ & $(4707.50)^{* *}$ & $(4652.54)^{* *}$ & $(4642.48)^{* *}$ & $(4700.14)^{* *}$ & $(4646.07)^{* *}$ & $(4647.46)^{* *}$ \\
\hline \multirow[t]{2}{*}{ _Iedu_4 } & 57505.34 & 56955.07 & 66003.97 & 53605.51 & 55100.38 & 63017.82 & 51154.58 & 50401.36 \\
\hline & $(4761.87)^{* *}$ & $(4811.33)^{* * *}$ & $(4877.01)^{* *}$ & $(4939.89)^{* * *}$ & $(4927.91)^{* *}$ & $(4898.14)^{* * *}$ & $(4958.27)^{* * *}$ & $(4956.81)^{* *}$ \\
\hline \multirow[t]{2}{*}{ autonom } & 26091.63 & 24733.64 & 27264.37 & 27489.93 & 31112.86 & 17450.15 & 18248.53 & 19968.92 \\
\hline & $(5128.05)^{* *}$ & $(5282.35)^{* *}$ & $(5245.84)^{* *}$ & $(5162.55)^{* * *}$ & $(5075.63)^{* *}$ & $(5399.47)^{* *}$ & $(5314.20)^{* * *}$ & $(5294.09)^{* *}$ \\
\hline \multirow[t]{2}{*}{ perminc } & & 3861.35 & 3625.2 & 3797.16 & -1531.19 & 210850.6 & 202634.9 & 34409.89 \\
\hline & & $(1405.23)^{* *}$ & $(1522.20)^{*}$ & $(1498.78)^{*}$ & $(477.80)^{* *}$ & $(50514.14)^{* *}$ & $(49813.47)^{* *}$ & $(8462.08)^{* *}$ \\
\hline \multirow[t]{2}{*}{ zeroinc } & & 51212.75 & 50227.54 & 50079.31 & & 459353.3 & 445005.6 & \\
\hline & & $(13073.22)^{* *}$ & $(13560.58)^{* *}$ & $(13352.82)^{* *}$ & & $(131687.60)^{* *}$ & $(129859.00)^{* *}$ & \\
\hline \multirow[t]{2}{*}{ expft02 } & & & 1510.98 & 1427.63 & 1510.17 & 1532.98 & 1447.12 & 1430.37 \\
\hline & & & $(176.86)^{* * *}$ & $(174.68)^{* * *}$ & $(173.43)^{* * *}$ & $(176.43)^{* *}$ & $(174.29)^{* * *}$ & $(174.35)^{* * *}$ \\
\hline \multirow[t]{2}{*}{ expmiss } & & & 74982.17 & 82049.11 & 85234.28 & 74771.73 & 81709.42 & 82005.66 \\
\hline & & & $(13661.36)^{* *}$ & $(13454.62)^{* *}$ & $(13439.06)^{* *}$ & $(13616.15)^{* *}$ & $(13413.66)^{* *}$ & $(13422.65)^{* *}$ \\
\hline \multirow[t]{2}{*}{ exppt02 } & & & 2418.59 & 2127.19 & 2096.76 & 2668.05 & 2362.66 & 2332.56 \\
\hline & & & $(230.58)^{* *}$ & $(228.02)^{* *}$ & $(228.07)^{* * *}$ & $(232.42)^{* * *}$ & $(229.88)^{* * *}$ & $(229.87)^{* *}$ \\
\hline \multirow[t]{2}{*}{ expue02 } & & & -620.86 & -785.1 & -1148.46 & -106.51 & -304.07 & -274.87 \\
\hline & & & $(765.35)$ & (753.24) & (747.61) & $(767.90)$ & (755.92) & (756.39) \\
\hline notlabor & & & 1570.48 & 1421.61 & 1337.41 & 1578.53 & 1429.12 & 1442.85 \\
\hline & & & $(191.20)^{* * *}$ & $(188.86)^{* *}$ & $(187.67)^{* *}$ & $(190.72)^{* *}$ & $(188.43)^{* *}$ & $(188.52)^{* * *}$ \\
\hline hiedu_f & & & & 33751.01 & 34548.15 & & 32281.84 & 33001.5 \\
\hline & & & & $(5956.53)^{* * *}$ & $(5957.73)^{* *}$ & & $(5943.02)^{* *}$ & $(5943.41)^{* *}$ \\
\hline hiedu_m & & & & -6411.22 & -6603.15 & & -5485.04 & -7842.25 \\
\hline & & & & (15001.76) & (15014.26) & & (14972.85) & (14967.36) \\
\hline hiedu_p & & & & -4887.54 & -6417.6 & & -6619.89 & -3928.87 \\
\hline & & & & (19504.51) & (19516.61) & & (19463.17) & (19460.74) \\
\hline inheri1 & & & & 51744.07 & 51517.35 & & 51223.24 & 51231.05 \\
\hline & & & & $(4440.93)^{* *}$ & $(4444.25)^{* *}$ & & $(4428.08)^{* * *}$ & $(4431.13)^{* *}$ \\
\hline inheri2 & & & & 49314.67 & 49279.3 & & 49478.4 & 49181.85 \\
\hline & & & & $(5206.37)^{* *}$ & $(5210.74)^{* *}$ & & $(5191.22)^{* *}$ & $(5194.08)^{* *}$ \\
\hline inc2 & & & & & & -31253.17 & -29889.49 & -9223.15 \\
\hline & & & & & & $(6409.68)^{* *}$ & $(6320.67)^{* *}$ & $(1893.70)^{* *}$ \\
\hline inc 3 & & & & & & 1462.81 & 1396 & 568.73 \\
\hline & & & & & & $(267.35)^{* *}$ & $(263.63)^{* *}$ & $(106.00)^{* *}$ \\
\hline Constant & 52764.24 & 10131.79 & -27474.47 & -28165.55 & 20145.55 & -437019.8 & -423413.5 & 21114.25 \\
\hline & $(3855.02)^{* *}$ & $(13527.82)$ & $(15324.07)$ & $(15091.77)$ & $(7869.94)^{*}$ & $(131786.90)^{* *}$ & $(129957.10)^{* *}$ & $(7858.71)^{* *}$ \\
\hline Observations & 7803 & 7803 & 7803 & 7803 & 7803 & 7803 & 7803 & 7803 \\
\hline $\begin{array}{l}\text { Adjusted R- } \\
\text { squared }\end{array}$ & 0.12 & 0.13 & 0.15 & 0.17 & 0.17 & 0.15 & 0.18 & 0.18 \\
\hline
\end{tabular}

Note: * significant at $5 \%$ level; ** significant at $1 \%$ level Source: SOEP 2002 